\title{
50. TECTONIC SETTING AND PROCESSES OF MUD VOLCANISM ON THE MEDITERRANEAN RIDGE ACCRETIONARY COMPLEX: EVIDENCE FROM LEG 1601
}

\author{
Alastair H.F. Robertson ${ }^{2}$ and Achim Kopf ${ }^{3}$
}

\begin{abstract}
Mud volcanism was initiated when overpressured muds rose through the Mediterranean Ridge accretionary prism. Early mud volcanism was marked by eruption of coarse clastic sediments forming small cones of debris flow deposits and turbidites, followed by eruption of large volumes of clast-rich matrix-supported debris flows. Eruption was accompanied by progressive subsidence to form moat-like features. Later, clast-poor mud flows spread laterally and built up a flat-topped cone (Napoli mud volcano). Clasts in the mud volcano sediments are mainly angular and up to $0.5 \mathrm{~m}$ in size. These clasts are dominated by claystone, sandstone, and limestone of early-middle Miocene age that were previously accreted. Matrix material of the mud breccias probably originated from Messinian evaporite-rich sediments located within the décollement zone beneath the accretionary wedge, at an estimated depth of 5-7 km. Pressure release triggered hydrofracturing of poorly consolidated mud near the seafloor. Eruption was accompanied by release of large volumes of hydrocarbon gas. Conditions were suitable for gas hydrate genesis at shallow depths beneath the seafloor at the Milano mud volcano. The mud volcanism is probably related to backthrusting concentrated along the rear of the accretionary wedge near a backstop of continental crust to the north. Clasts within the mud breccias were mainly derived from the North African passive margin, but subordinate lithoclastic ophiolite-related material was also derived from the north, probably from now largely obliterated higher thrust sheets of Crete. Comparisons show that in contrast to other mud volcanoes both on the seafloor (Barbados) and on land (Trinidad), which are usually relatively transient features, mud volcanism on the Mediterranean Ridge has persisted for $>1$ m.y. A revised hypothesis of mud volcanism at the Ocean Drilling Program sites is proposed, in relation to progressive tectonic evolution of the Mediterranean Ridge accretionary complex.
\end{abstract}

\section{INTRODUCTION}

An intriguing aspect of Mediterranean deep-sea research in recent years has been the discovery of active mud volcanoes on the Mediterranean Ridge south of Crete (Cita et al., 1981; 1989, 1996; Fig. 1). Mud volcanoes occur in a very wide variety of other settings under the sea and on land (Brown and Westbrook, 1988; Higgins and Saunders, 1974; Yassir, 1989). Common occurrences associated with marine accretionary prisms include Barbados (Langseth et al., 1988; Langseth and Moore, 1990), Cascadia (Sample et al., 1993; Westbrook, Carson, Musgrave et al., 1994), Costa Rica (Shipley et al., 1990), Panama (Reed et al., 1990), and the Japan trench (Morgan and Karig, 1995). Mud volcanoes on land include examples in Indonesia (Barber et al., 1986), Japan (Agar, 1990), Trinidad (Beeby-Thompson, 1910), Taiwan (Shih, 1967), on the island of Sakalin in Russia (Vereshchagin and Kovtunovich, 1970), and in Aberbyzhan (Jakubov et al., 1991). Additional examples are found, for example, in the Californian Coast Ranges, Armenia, Nicobar Islands, the Kurriles and Kamchatka (Higgins and Saunders, 1974; Yassir, 1989). Mud volcanism in non-accretionary settings include the Black Sea (Limonov et al., 1994, 1997), Alboran Sea, Gulf of Mexico (e.g., Louisiana coast), and the Caspian and Salton Seas (Higgins and Saunders, 1974).

In this synthesis, we will first summarize key post-cruise results that supplement initial shipboard studies of the mud volcanoes (Emeis, Robertson, Richter, et al., 1996; Robertson et al., 1997; Kopf

${ }^{1}$ Robertson, A.H.F., Emeis, K.-C., Richter, C., and Camerlenghi, A. (Eds.), 1998. Proc. ODP, Sci. Results, 160: College Station, TX (Ocean Drilling Program).

${ }^{2}$ Department of Geology and Geophysics, University of Edinburgh, West Mains Road, Edinburgh EH9 3JW, United Kingdom. Alastair.Robertson@glg.ed.ac.uk

${ }^{3}$ Geologisches Institut, Albert-Ludwigs-Universität Freiburg, Albertstrasse 23B, 79104 Freiburg, Federal Republic of Germany. et al., in press). We will then outline current knowledge of the present-day tectonic setting of the Mediterranean Ridge accretionary complex in relation to mud volcanism, and go on to discuss the Mesozoic-Holocene tectonic development of the southerly Neotethyan basin in which the mud volcanoes developed. This, in turn, allows an interpretation of the Neogene to Holocene tectonic-sedimentary history of the Mediterranean Ridge accretionary complex. We summarize existing models for the Mediterranean mud volcanoes and conclude with a revised, integrated hypothesis for the mud volcanoes drilled during Leg 160.

The story begins with the later stages of development of the North African passive margin to the south, and the collision history of Neotethys along the Eurasian margin to the north; it continues with the development of the Mediterranean Ridge as a mud-dominated accretionary complex punctuated by the Mediterranean salinity crisis, and culminates in collision of the accretionary complex with the North African passive margin to the south, a process that is continuing.

\section{SUMMARY OF THE LEG 160 EVIDENCE}

The main new results from the Milano and Napoli mud domes (Figs. 1,2) that must be explained by any tectonic hypothesis are discussed below.

\section{Age of Initiation}

The drilling has demonstrated the age of the mud volcanoes in a way that would never have been possible by piston coring and dredging alone. Both mud volcanoes were found to be more than $1 \mathrm{Ma}$ old, much older than previously envisioned, even though we cannot be certain to have penetrated the base of the mud flows (Emeis, Robertson, Richter, et al., 1996). Previous piston coring suggested ages of up to around $100 \mathrm{ka}$ (Camerlenghi et al., 1992, 1995). This $\sim 1$ Ma age

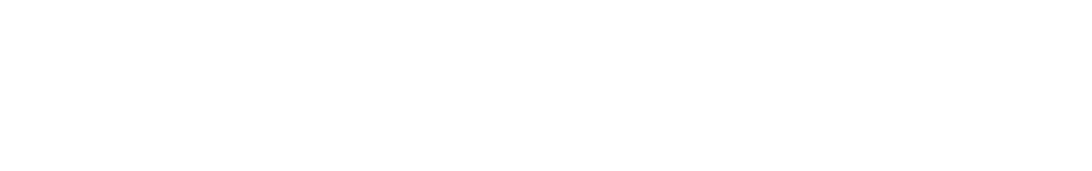


is also unprecedented, compared to known ages of mud volcanoes in other accretionary settings (e.g., <200 ka in Barbados; Henry et al. 1990), and requires explanation in any tectonic hypothesis.

\section{Mud Volcanism vs. Mud Diapirism}

The drilling has resolved the long-standing controversy over the mode of formation of the mud breccia at least in the two mud structures drilled: were they, partly or totally, viscous intrusions, as favored by Cita et al. (1989), Premoli-Silva et al. (1996), or alternatively sedimentary debris flows extruded onto the seafloor (in Limonov

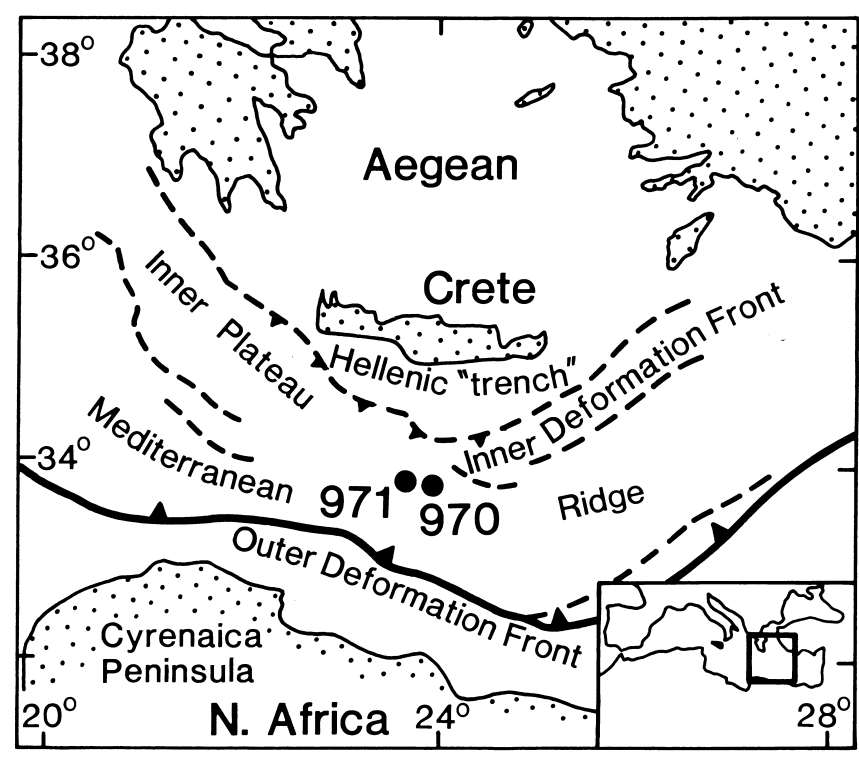

Figure 1. Outline tectonic setting of the Milano (Site 970) and Napoli (Site 971) mud volcanoes on the Mediterranean Ridge south of Crete. These volcanoes are located on the northern part of the Inner Plateau area, adjacent to the Hellenic Trench to the north. Note the location of the Cyrenaica peninsula of the North African continental margin to the south. et al., 1994). Earlier studies of piston cores (Staffini et al., 1993) revealed several different types of "mud breccias," including layered and organized types. The latter were interpreted as debris flow deposits and turbidites. However, associated massive facies were seen as mainly intrusive in origin.

The combined drill recovery and log data demonstrate that the mud breccias of both the mud volcanoes were constructed of multiple extrusions of debris flows rather than intrusive mud breccias, based on the following lines of evidence: (1) interfingering of mud breccias with hemipelagic sediments, (2) sedimentary layering and finingupward successions (the latter in polymict gravels) in the mud breccias, and (3) absence of mud dikes cutting hemipelagites.

\section{Anatomy of the Mud Volcanoes}

The combined core and geophysical logs, especially using the Formation MicroScanner (FMS), allow the history of mud volcanism to be reliably reconstructed for the first time (Fig. 3). In both the Milano and Napoli mud volcanoes graded silts and matrix-supported clay-rich rudites are present low in the succession. The lowest parts of the succession recovered within the Milano mud volcano (Hole 970A), includes thin, graded partings rich in terrigenous silt interpreted as accumulations from dilute turbidites, and matrix-supported, coarse clay-rich sediments interpreted as debris flow deposits. These early layered, sediments are overlain by volumetrically dominant massive, clast-rich, mud-supported sediments in both mud volcanoes, interpreted as multiple clay-rich debris flow deposits.

In addition, the drilling indicates that moat-like features are present around both mud volcanoes. The moat around the Milano mud volcano is sediment filled, whereas Napoli is underfilled. Inward-dipping reflectors are seen on seismic lines beneath the moats, and interpreted in terms of progressive collapse during mud volcanism. The ages of the mud flows within the moat at Milano indicate these features have a long history of formation (Robertson et al., 1996). Similar moat-like structures are present around some of the Barbados (Langseth and Moore, 1990), Black Sea (Limonov et al., 1997) and other mud volcanoes. Calculations indicate that the formation of peripheral moats requires expulsion of large volumes of fluid (Henry et al., 1996).
Figure 2. Location of the mud volcanoes of the Olimpi field including the Milano and Napoli structures drilled, together with other mud volcanic areas on the Mediterranean Ridge accretionary complex. Additional mud volcanoes were more recently discovered northwest of the Gelendzhik and Prometheus 2 structures (Hieke et al., 1996b). See text for data sources.

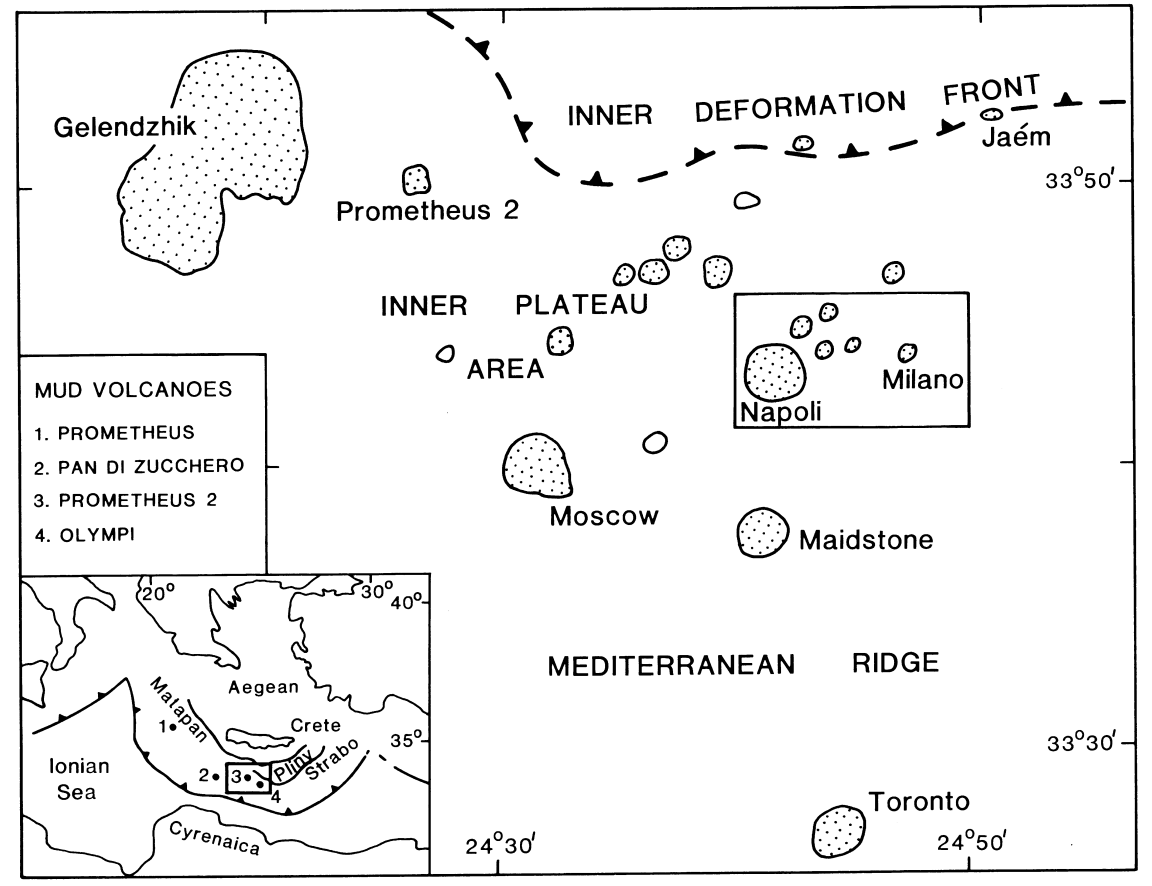




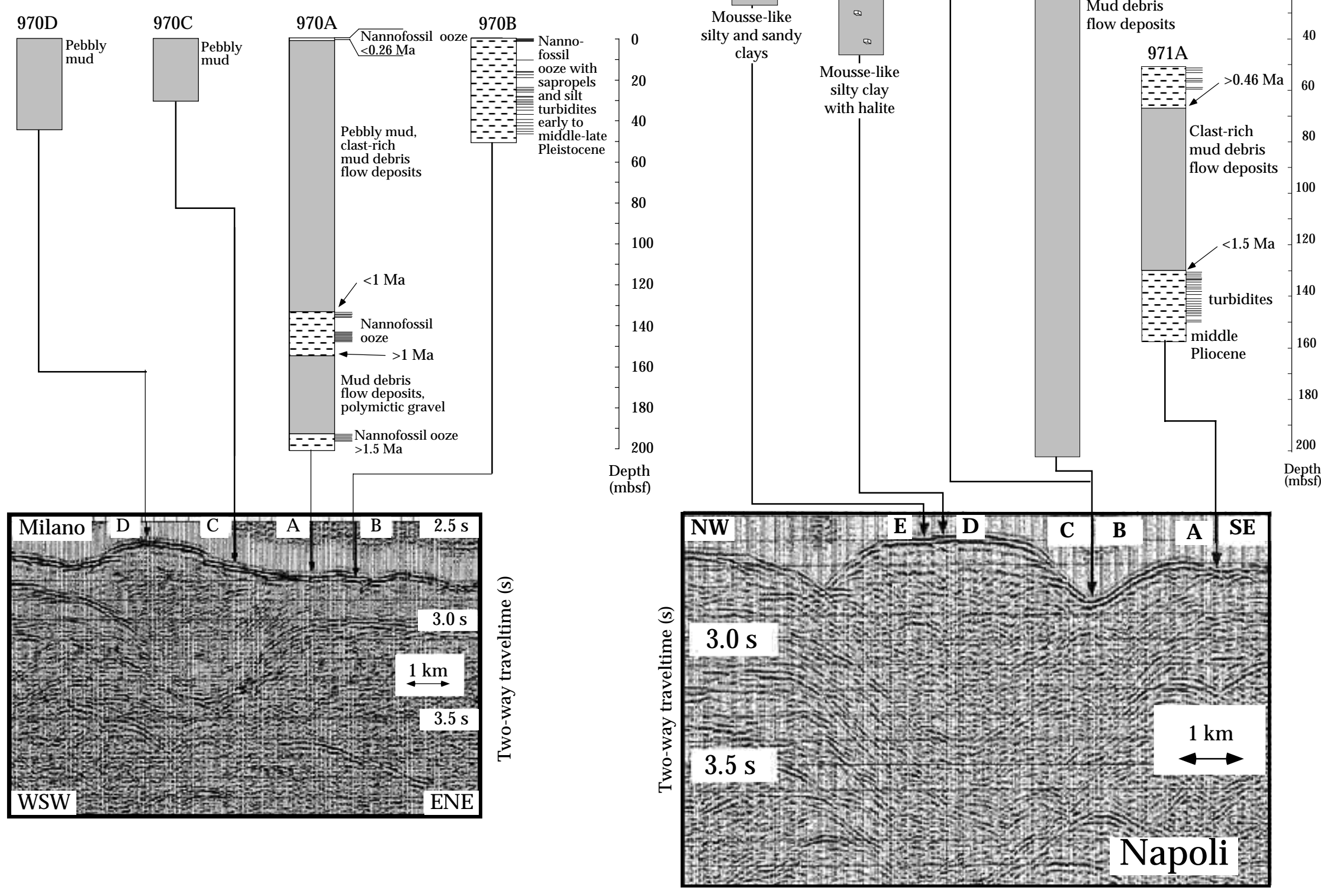

Figure 3. Summary of the successions recovered from the Milano and Napoli mud volcanoes. Modified after Emeis, Robertson, Richter, et al. (1996). 
In summary, drilling of more or less the entire eruptive succession at the Napoli and Milano mud volcanoes indicates a systematic sequence of events: (1) early eruptive activity formed a clastic cone; (2) overlying clast-rich debris flows represent relatively viscous debris flows; (3) extrusion of the debris flows occurred over an extended time interval during which progressive subsidence took place to form the moat-like structure around Napoli; and (4) the crestal area of the Milano comprises later-stage sandy deposits with sedimentary bedding.

\section{Origin of Matrix}

Well-preserved textures of clast and matrix were recovered by drilling for the first time, although overall recovery of the debris flows was poor (Emeis, Robertson, Richter, et al., 1996; Flecker and Kopf, 1996). Two hypotheses for the origin of the clasts vs. the matrix can be considered. First, the clasts and the matrix were derived from the same stratigraphic units. In this hypothesis, the matrix consists largely of finely comminuted rock fragments, in effect finergrained equivalents of the clast lithologies, with no additional material. This alternative is generally supported by petrographic evidence that the silty and sandy components of the matrix (studied in impregnated thin sections) are mainly similar to the clasts themselves (Robertson and Kopf, Chap. 45, this volume). In the second hypothesis, the matrix is of a different origin than the clasts (i.e., from a different stratigraphic unit, or units). The latter option is supported by the following:

1. Most claystone and mudstone clasts, and the matrix are unfossiliferous, in contrast to the highly fossiliferous nature of Miocene calcareous sediments forming many of the clasts.

2. The muds locally contain Ammonium becarii, a benthic foraminifer, characteristic of a late Miocene low-salinity "Lago Mare setting" (Spezzaferri et al., Chap. 2, this volume).

3. Residues derived from mud and clay samples that were washed for microfossils contain dolomite, which suggests an evaporitic origin (S. Spezzaferri, pers. comm., 1996).

4. The clay mineral fraction includes minor Fe-illite for which an evaporitic setting is again likely (Jurado-Rodríguez and Martínez-Ruiz, Chap. 47, this volume).

In summary, the evidence supports derivation of much of the matrix of the Napoli mud volcano from a Messinian evaporitic unit, whereas the clasts were derived from Miocene (pre-Messinian) clastic and carbonate units. However, some of the matrix was probably also provided by fluidization of argillaceous sediments within preMessinian units. It is also possible that the matrix came from different sources in different mud volcanoes (see below).

\section{Vitrinite Reflectance Data}

Organic maturation data suggest derivation from depth, in and around the décollement zone at 5-7 km depth (Schulz et al., 1997). Having applied the Lopatin method for modeling maturation from vitrinite reflectance, the depth from which the mud originated is estimated to be between $4.9 \mathrm{~km}$ and $7.5 \mathrm{~km}$ (Schulz et al., 1997). The time available for maturation is constrained as between the time of subduction during the Messinian and the time of eruption, or $~ 1.5$ Ma, based on the Leg 160 evidence.

Recently, additional vitrinite reflectance data from the clasts of the Milano mud volcano show that the clasts underwent only shallow burial (A. Kopf, unpubl. data), suggesting that more work on the depth of origin of the clasts vs. matrix is needed.

\section{Provenance of Clasts}

It was previously assumed that all the sedimentary material was ultimately derived from the North African passive continental margin to the south (Staffini et al., 1993; Akhmanov, 1996). This is indeed true for the volumetrically dominant mature quartzose sandstone (litharenites) and some redeposited shallow-water and pelagic carbonates. However, the Leg 160 sandstone clasts also include a small, but significant amount of previously unrecognized lithic material, including metamorphic quartzite, altered basalt, serpentinite and radiolarian chert (Robertson and Kopf, Chap. 45, this volume). The only plausible source for this is the orogenic areas of the Eurasian landmass to the north (Crete and the adjacent south Aegean). Some other clasts of lithic sandstones mentioned in earlier petrographic reports (Staffini et al., 1993; Akhmanov, 1996) could have a similar northerly origin and existing data should be reassessed with this in mind.

\section{Age of Clasts}

During Leg 160, clasts of Burdigalian age were observed to be the oldest sediments present, based on the ages of the microfossils that were of primary pelagic deposition and not reworked. Cretaceous and Eocene microfossils are also present, but these are reworked together with younger microfossils within the clasts (Emeis, Robertson, Richter, et al., 1996; Robertson et al., 1996). Additional material recovered from different volcanoes in the Olimpi field during TREDMAR cruises (Limonov et al., 1994, 1996) also yielded nannofossils and pelagic foraminifers of mainly Miocene age, with some Pliocene, Oligocene, and rare Cretaceous forms, many of which were also reworked (Premoli-Silva et al., 1996). Implications of the Leg 160 results are: (1) Ages can only be inferred from clasts, since there is no way of distinguishing reworked microfossils within the matrix alone; (2) Some earlier published ages of clasts may need to be reassessed in view of the possible role of reworking.

\section{Permeability of Matrix}

Physical property measurements carried out routinely during the cruise (i.e., water content, bulk and grain density, porosity, Vane shear strength; Emeis, Robertson, Richter, et al., 1996), were supplemented by postcruise shear box experiments, particle size analysis, determination of Atterberg limits, and permeability tests on undisturbed cores. The combined evidence shows that permeabilities are very low for all the mud breccia varieties (Kopf et al., Chap. 48, this volume), ranging from values one to two orders of magnitude lower than for deep-sea clays (Schultheiss and Gunn, 1985). Natural water contents were commonly found to be close to the liquid limit of the sediments, so that an in situ behavior similar to that of a fluid is inferred for the muds (Kopf et al., Chap. 48, this volume).

\section{Evidence of Overpressuring at Depth}

The data obtained from Leg 160 support the role of overpressured fluids in mud volcanism, on the basis of the following:

1. Anastomosing and cross-cutting veinlets are commonly observed within angular claystone clasts. These textures are interpreted as hydrofracturing, the result of fluid escape and fragmentation. These processes were probably active when overpressured fluidrich clays rapidly reverted to near hydrostatic pressures during mud volcanic eruption near the seafloor (Robertson and Kopf, Chap. 45, this volume).

2. Mud breccias from the deeper holes, as well as mousse-like sediments from the crestal holes, reveal apparently undeformed textures of clay particles and aggregates, suggesting that high pore 
pressures spared these sediments from disruption and shearing during ascent within the mud volcano plumbing system (Robertson and Kopf, Chap. 45, this volume).

3. By contrast, when sheared under normal consolidation, or only slightly overconsolidation, shear bands and microveins develop (Behrmann, 1991; Kopf et al., Chap. 48, this volume). Study of cores from the Cascadia margin has revealed similar structures including anastomosing veins, shear bands, incipient scaly fabrics and blocky mosaic structures that allow fluid flow when held open by high pore pressures (Clennell and Maltman, 1995). Anastomosing scaly clay was also observed in the toe region off Barbados (Prior and Behrmann, 1990). In addition, scaly fabrics are observed in many examples of matrix-supported conglomerates within accretionary prisms on land. These units include debris flow deposits, olistostromes, and melanges of variable types (e.g., southwest Japan; Agar, 1990). Scaly fabrics are also known to be associated with wrench faulting (in Timor: Barber et al., 1986; in Trinidad: Higgins and Saunders, 1974).

\section{Depth of Origin of the Matrix}

Alternatives are either a relatively deep (several $\mathrm{km}$ ) or a relatively shallow origin. (1) A deep origin of the mud was inferred from vitrinite reflectance data for the Napoli mud volcano (Schulz et al., 1997), but more recent data from the clasts of the Milano mud volcano suggest shallower depths (A. Kopf, unpubl. data). (2) Shipboard organic geochemical results (Emeis, Robertson, Richter, et al., 1996) support earlier results (Camerlenghi et al., 1995), indicating the presence of mature hydrocarbons within the mud volcano sediments, requiring an origin of estimated $>2 \mathrm{~km}$ depth. (3) The common presence of ankerite in the matrix suggests deep burial diagenesis of several kilometers (Robertson and Kopf, Chap. 45, this volume). (4) Clasts of halite were locally recovered at the crest of the Napoli mud volcano. The Messinian in the Olimpi area is relatively thin, based on limited seismic evidence, suggestive of deposition on a topographic high. Evaporites on a topographic high are expected to be dominated by gypsum, without halite, based on comparisons with on-land marginal settings (Crete and Cyprus), but gypsum was not found in the two mud volcanoes drilled. The implication is that the halite was derived from a greater depth, either within an accretionary wedge several kilometers beneath, or at still greater depth from the present-day décollement zone estimated at 5-7 km mbsf (Camerlenghi et al., 1995). A possibly shallow $(<2 \mathrm{~km})$ origin of some of the matrix is apparently supported by the clay mineralogical evidence of smectite and kaolinite, which does not indicate very deep burial diagenesis (Robertson and Kopf, Chap. 45, this volume). However, the apparent absence of clay alteration could be a consequence of overpressuring of mud within the subduction zone.

\section{Role of Methane Gas}

The presence of very gassy sediments, mainly methane, associated with the Napoli mud volcano confirms earlier discoveries of mousse-like sediments in piston cores (Cita et al., 1989; Emeis, Robertson, Richter, et al., 1996). The gas-rich sediments expand explosively when brought to the surface in cores. However, gas-driven explosive eruption on the seafloor is not anticipated at water depths in excess of 2000 mbsf (Brown, 1990). Fragments of aragonite, possibly representing original crusts were observed in the Olimpi mud volcanoes (Robertson and Kopf, Chap. 45, this volume). Formation of such carbonate crusts implies fluid expulsion and oxidation of methane, as observed in Barbados (Le Pichon et al., 1990), the Black Sea (Belenkaia, 1997) and elsewhere. Venting gas-rich fluids were observed on the Mediterranean Ridge (Limonov et al., 1994). Bacterial methanogenesis associated with oxidation of thermogenic hydrocar- bons has been described from isotopic study of carbonate cements from the Cascadia accretionary prism (Sample and Kopf, 1995).

\section{Importance of Gas Hydrates}

Low chlorinity of the pore waters in the Milano mud volcano demonstrates the presence of large amounts of gas hydrate at shallow depths tens of meters beneath the seafloor (De Lange and Brumsack, Chap. 44, this volume). In the Napoli mud volcano, pore water studies indicate that gas hydrates are likely to be restricted to minor amounts within superficial sediments (i.e., $<1 \mathrm{mbsf}$ ). Gas hydrates in the Mediterranean mud domes are restricted to shallow depths beneath the sea floor by a combination of water depth, geothermal gradient, bottom-water temperatures of $\sim 14^{\circ} \mathrm{C}$ and interstitial fluid composition (brines). Thus, small changes in ambient temperature may greatly affect the stability of the gas hydrate. At present, large quantities of natural gas may be trapped within the Milano mud volcano beneath a capping of impermeable gas hydrate (De Lange and Brumsack, Chap. 44, this volume), with implications for any future mud volcanism. Indeed, gas hydrates may have alternately formed and decomposed during dormant and active stages of mud volcanism.

By varying sediment density, the presence of gas hydrates is an important additional potential force of buoyancy for mud volcanism could be provided by decomposition of gas hydrates trapped below an impermeable seal. Massive gas hydrates are, for example, present off Costa Rica (Kimura, Silver, Blum, et al., in press), an area where mud domes are known to exist.

\section{MUD VOLCANISM ON THE MEDITERRANEAN RIDGE AND COMPARISONS}

The Olimpi field and its vicinity is now one of the best investigated mud volcano areas of the world (e.g., Cita et al., 1981, 1989; Camerlenghi et al., 1992, 1995; Limonov et al., 1994, 1996; Westbrook et al., 1995; Ivanov et al., 1996; Hieke et al., 1996b; Cronin et al., 1997). The mud features vary in scale, shape, and nature of origin. The majority of the topographic highs are located near the southern margin of the Inner Deformation Front of the Mediterranean Ridge (Figs. 1, 2). The size of the mud volcanoes in the Olimpi area ranges from $0.68-3.52 \mathrm{~km}$ at their base, with a relief between $60 \mathrm{~m}$ and 130 $\mathrm{m}$ above the surrounding seafloor (Camerlenghi et al., 1995). Many of the structures are asymmetric in cross section, with depressions on the flanks. The largest features, like Gelendzhik (Fig. 2), cover a vast area up to $140 \mathrm{~km}^{2}$ (Limonov et al., 1994). Deep-tow sonographs reveal flow structures and patchy subcircular features. The latter are interpreted as pockmarks indicating fluid venting (Hieke et al., 1996b). Within the crater areas of mud volcanoes, clasts several meters in diameter were observed with video equipment at the Stoke-on-Trent and Dublin mud volcanoes (Cronin et al., 1997). Molluscs cored from the Napoli dome are attributed to the presence of cold seeps of methane-rich solutions from which energy was released by bacterial chemosynthetic activity (Corselli and Basso, 1996). Similarly, at Barbados and elsewhere the expulsion of fluids is associated with chemosynthetic animal communities (Le Pichon et al., 1990).

Sidescan sonar studies show that the Olimpi field is dominated by sub-circular structures, within an overall northwest-southeast trend, parallel to the Olimpi escarpment to the southwest. Additional, more elongate mud structures, mainly mud ridges, are present further northwest, including Prometheus 2 (Fig. 2), and these are oriented in the same direction. In addition, a small number of mud structures are located to the southwest of the bordering Olimpi escarpment (Hieke et al., 1996b). Long-range sidescan sonar records of the Olimpi field reveals a pattern of southward concave features bending around the mud volcano area and deforming Pliocene-Pleistocene sediments. 
These structures are generally symmetric, with an average separation of $750 \mathrm{~m}$, and individual lengths of several kilometers.

Regional long-range sidescan sonar study of the Eastern Mediterranean shows that about 150 circular to sub-circular patches occur mainly on the shallower and northern parts of the Mediterranean Ridge where the Messinian salt is relatively thin (Fusi and Kenyon, 1996). These features are interpreted as mud volcanoes and mud ridges with mud breccias exposed on the seafloor. The inferred mud structures occur in groups and form elongate trends parallel to structures within the ridge. Mud structures are less common where salt is thicker, including parts of the Cyprus and Calabrian arc surveyed. However, mud structures (mainly ridges) do occur in the summit area of the Mediterranean Ridge (Hieke et al., 1996a). Mud volcanoes were also were recently found within the Anaximander Mountain area near the easterly termination of the Mediterranean Ridge where they again appear to be structurally controlled (Woodside, 1997). A number of other reflective features identified by Fusi and Kenyon (1996) are interpreted as brine pools and other bodies that are not discussed here.

The diversity of morphologies of Mediterranean Ridge mud volcanism is mirrored in other areas. For example, three main types of mud structure are observed associated with the Barbados accretionary prism, mainly located seaward of the deformation front: (1) Mud volcanoes that show "rippled" and lobate surfaces and appear to be mostly active; (2) Flat-topped "mud pies" that are concentric to elliptical, and are set below the seafloor within a broad, subsiding basin, comparable with the Napoli mud volcano; (3) Diapirs, which are apparently piercement structures, as suggested by evidence of uplift and marginal deformation, comparable with some of the mud ridges on the Mediterranean ridge. In general, seismic studies show that the Barbados mud volcanoes taper downward and then widen into a deep reservoir of mud (Brown and Westbrook, 1988). Unfortunately, the conduits of the Mediterranean Ridge mud volcanoes have not been imaged. In Barbados, the conical mud volcanoes are inferred to be relatively early features, whereas the larger flat-topped "mud pies" represent later stages of development, a chronology that may also apply to the Milano and Napoli mud volcanoes (see later). The Barbados mud volcanoes appear to be relatively small ephemeral features ( $<200 \mathrm{ka}$ ), that will ultimately be subducted, in contrast to the Mediterranean Ridge mud volcanoes that are much more long lived (about $1 \mathrm{Ma}$ ) and have a high chance of eventual preservation in the stratigraphic record, as they located on the upper plate of the convergence zone.

In the Black Sea elongate mud domes and ridges of different shape and size are mainly located in the central part of the Black Sea at water depths below $2 \mathrm{~km}$, mainly south of the Crimean Peninsula (Ivanov et al., 1996; Limonov et al., 1997). The Black Sea mud volcanoes are mushroom- to cone shaped, and rarely flat-topped, similar to the Napoli mud volcano, with seafloor diameters of $1-3 \mathrm{~km}$ vertical relief ranging from 20-150 m (Ivanov et al., 1996; Limonov et al., 1994, 1997). Collapse features are also observed, similar to those of the Napoli mud volcano. Clasts recovered from the mud structures are Oligocene-Miocene and younger in age, compatible with a depth of origin down to approximately $7 \mathrm{~km}$ (Tugoleslov et al., 1985; Limonov et al., 1997), emphasizing the possibility of deep origins. Feeder channels of the various seafloor mud structures can be identified at depth on seismic lines (Gainanov, 1997), in contrast to the Mediterranean Ridge mud volcanoes. These feeder channels vary from an estimated 1-3.5 km in diameter (Limonov et al., 1994; Ivanov et al., 1996), although at any given time the active conduit of an individual mud volcano was probably very much narrower.

\section{TECTONIC SETTING OF MEDITERRANEAN RIDGE VOLCANISM}

The mud volcanoes drilled during Leg 160 are located in the central area of the Mediterranean Ridge accretionary complex (Fig. 4).
The mud volcanism is most extensive in this central area of the Mediterranean Ridge, although there are occurrences elsewhere (Camerlenghi, in press; Chaumillon and Mascle, in press; Chaumillon et al., in press; Fusi and Kenyon, 1996). Important questions for the formation of the mud volcanoes are (1) the location of the décollement of the downgoing slab (i.e., which parts of the incoming plate are being subducted and which accreted, and how this has varied through time); (2) the location and nature of the backstop of continental crust to the north; (3) the timing of initiation of the subduction that gave rise to the Mediterranean Ridge accretionary complex; (4) the timing of first collision of the North African passive margin with the trench.

The Eastern Mediterranean Sea in which the mud volcanoes formed was bordered to the south by the passive margin of North Africa (i.e., Gondwana) from Early Mesozoic time onwards (de Voogd et al., 1992), whereas the north of the basin was characterized by active margin processes during Neogene to Holocene time (Dercourt et al., 1993). Thus, the regional geology of both these areas is relevant to the setting of the mud volcanism.

The central area of the Mediterranean Ridge is in the process of colliding with the Cyrenaica promontory of North Africa. The contrasting eastern and western segments of the Mediterranean Ridge will not be discussed here (Fig. 4). The central area is characterized by a near orthogonal convergence rate of $3.8 \mathrm{~cm} / \mathrm{yr}$ (Chase, 1978). The outer part of the accretionary complex is about $55 \mathrm{~km}$ wide and is characterized by seismically imaged imbricate thrust sheets and a distinct topographic slope of the complex (Finetti, 1976, unpubl. data; Camerlenghi et al., 1992; Camerlenghi and Polonia, 1994, in press; Chaumillon and Mascle, 1995, in press).

Seismic data for the central area, north of the Cyrenaica Promontory, and nearest to the mud volcanoes is limited to one MCS line of 1970s data (Katia transect; Sancho et al., 1973). This shows that a foredeep is absent and that the accretionary wedge, the outer deformation front, is in direct tectonic contact with slope sediments of the North African passive margin. The PRISMED data for the wider area (Fig. 4) further suggest that typical Messinian evaporite-related reflecting sequences are generally absent over the crestal area of the Mediterranean Ridge, suggesting that this area was a topographic high during the Messinian (Chaumillon and Mascle, 1995, in press).

Superficial reverse faults within the accretionary complex in the central area are correlated with rare deep-dipping reflectors, as evidence of regional-scale thrusting and shortening (Chaumillon and Mascle, 1995, in press). One PRISMED line (PM 19) traverses the mud volcano field in the vicinity of the Toronto mud volcano (Fig. 4). The seismic reflection profile reveals numerous southwarddipping reflectors that can be interpreted as backthrusts (Fig. 4). A key question is whether or not the inferred backthrusts connect with a clearly imaged décollement surface at depth. Resolution is barely adequate to be certain about this, but the line drawing interpretation show that at least some of the reverse faults splay off the décollement (Chaumillon and Mascle, in press)

In summary, evidence for incipient continental collision in this central area of the Mediterranean Ridge, to the north of the Cyrenaica promontory, is provided by (1) near-continental crustal thickness between North Africa and Crete in this area; (2) molding of the tectonic lineaments within the accretionary wedge to the shape of the Cyrenaica promontory; (3) absence of any incoming abyssal plain succession; (4) maximum elevation of the Mediterranean Ridge; and (5) backthrusting over an inferred backstop of continental crust to the north.

To the north of the Mediterranean Ridge accretionary wedge, continental crust was initially inferred to underlie offshore Crete and the landward wall of the Hellenic Trench, based on the results of DSDP Leg 13 (Hsü et al. 1973; Ryan, Hsü, et al., 1973) and submersible observations (Le Pichon et al., 1982). This crust is now recognized as a backstop to the accretionary prism comprised of Cretan nappes (Le Pichon et al., 1982; Fig. 4).

In the west, the inner deformation front is marked laterally extensive zones of southwest-dipping reflections (Reston et al., 1995; Fig. 

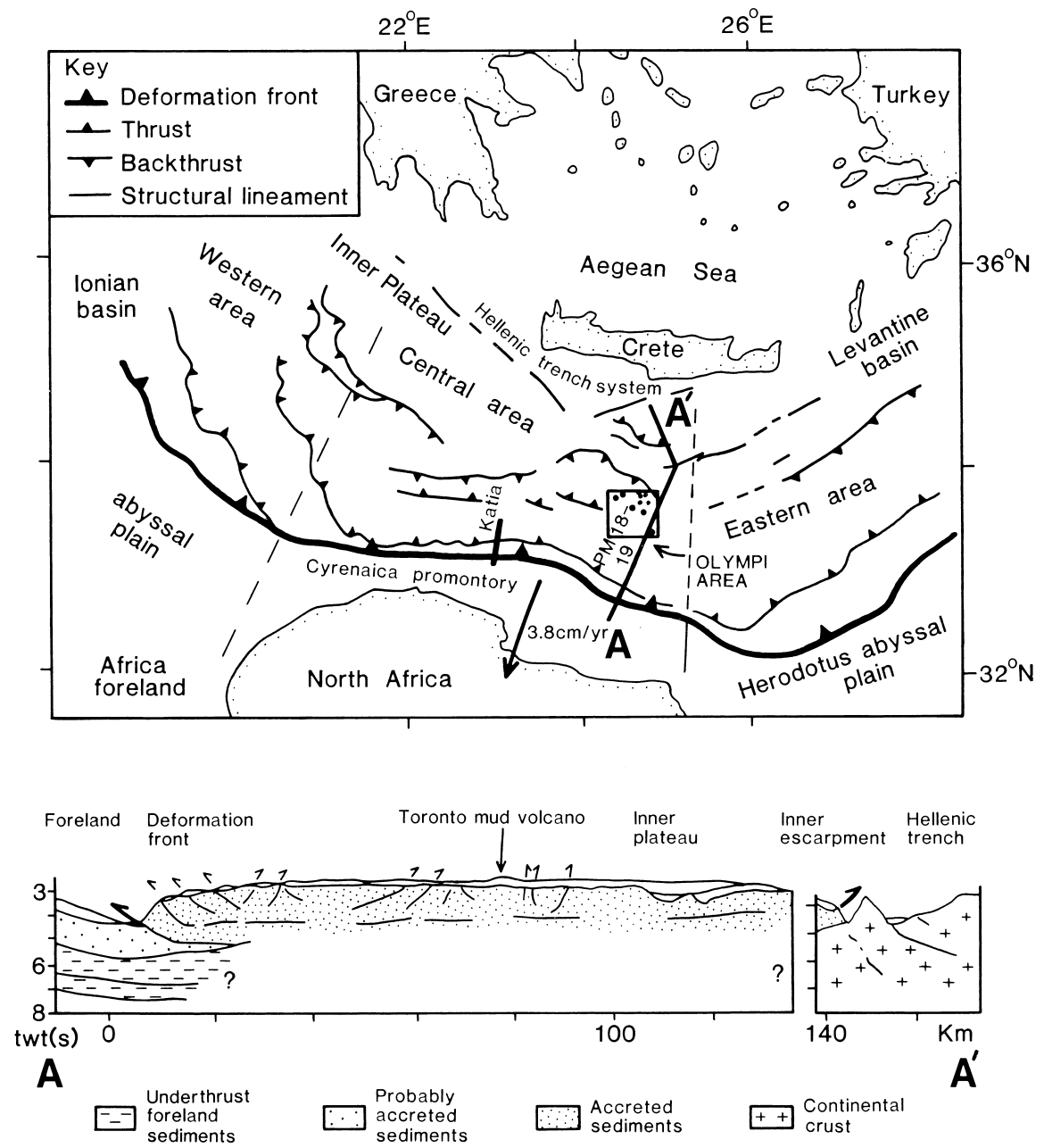

Figure 4. Structural elements of the Mediterranean Ridge inferred from seismic studies (Camerlenghi et al., 1995, in press; Chaumillon and Mascle, 1995, in press). The central area of the Mediterranean Ridge, in which the Leg 160 mud volcanoes are located, is undergoing orthogonal convergence and incipient continental collision. Upper: tectonic lineaments; lower: interpretation of seismic profiles (from the PRISMED data set; Chaumillon and Mascle, 1995, in press).

1). These zones are interpreted as the result of backthrusting against a backstop (Camerlenghi et al., 1995; Reston et al., 1995; Chaumillon and Mascle, 1995, in press).

Gravity modeling and ESP studies of the Mediterranean Ridge in the west (i.e., southwest of the Peloponnese; de Voogd et al., 1992; Truffert et al., 1993) suggest that a backstop of Cretan-type crust extends about $100 \mathrm{~km}$ oceanward of the Ionian branch of the Hellenic Trench in this area. However, it is unlikely that a continental crustal backstop extends beneath the Olimpi field in the central area of the Mediterranean Ridge as clasts of continental-type basement are not seen in the recovered mud breccias. Nevertheless, if crustal rock did underlie the Olimpi field, it might be too deep to be incorporated into the mud breccias.

The Hellenic Trench to the north of the Mediterranean Ridge is located in a general forearc setting that in the past has variably been interpreted as a subduction trench, a half-graben, a strike-slip controlled basin (in the east and west), and as a sediment-starved flexural foredeep (Huchon et al., 1982; Le Pichon et al., 1982; Lallement et al., 1994; Le Pichon et al., 1995). The trench was initially envisioned as a true subduction-related trench containing accreted material (Ryan, Hsü, et al., 1973). More recent work, including submersible observations, indicates that, whereas the seaward wall of the Hellenic Trench is undergoing compression, the landward wall is experiencing extension (Le Pichon et al., 1982), a stress regime that is inconsistent with steady-state subduction. This evidence instead favors interpretation of the Hellenic Trench central segment, north of the Olimpi mud volcano field, as a fault-disrupted and sediment starved foredeep related to backthrusting of the Mediterranean Ridge accretionary complex. In this setting, the foreland (i.e., the Cretan backstop) would ex- perience flexural loading towards the overthrust load (i.e., the Mediterranean Ridge) resulting in faulting and extension on the landward side, but compression on the seaward side, as is observed.

Where the continental backstop is exposed on Crete it is composed of a stack of subhorizontal thrust sheets that were emplaced related to closure of Neotethys during early Tertiary time (Seidel et al., 1982; Hall et al., 1984). Inferred ophiolitic material (serpentinite, basalt, radiolarian chert) within the mud volcano clasts and matrix can possibly be correlated with high-level nappes on Crete, whereas locally abundant plutonic and metamorphic material in lithoclastic sandstone clasts might have been derived from an even higher unit metamorphic unit. Limestone lithoclasts that could have been derived from Mesozoic carbonate platform units lower in the thrust stack are effectively absent.

Much of Crete is composed of carbonate platform units interpreted as a former microcontinent within the Neotethys ocean (i.e., known as Apulia or Adria). To the north there was another Neotethyan basin, the Pindos ocean, and to the north again, another microcontinent, represented by the Pelagonian zone (Fig. 5). The Pindos ocean was partly closed by Late Jurassic time, associated with the emplacement of ophiolites and mélange onto the Pelagonian microcontinent. However, a remnant of the Pindos ocean remained open into the early Tertiary (Robertson et al., 1991). The early Tertiary thrust and nappe emplacement in Crete relates to final closure of this remnant Pindos ocean (Fig. 6). Regional tectonic lineaments were oriented approximately east-west (Fig. 5), based on paleomagnetic data, but were deformed to create the Aegean arc (Kissel and Laj, 1988).

Far-traveled, more northerly derived, metamorphic and plutonic igneous rocks form the highest levels of the thrust stack. These in- 
clude the basement of the Pelagonian microcontinent and ophioliterelated units initially emplaced in the Jurassic (Fig. 6). Lower levels of the thrust stack include deep-sea sedimentary and marginal units of the Pindos ocean, and beneath this mainly shallow-water carbonates, representing the southerly microcontinent (part of Apulia, or Adria), located north of the southerly Neotethyan basin (Fig. 6).

Overthrusting of the northerly-derived thrust stack was complete by the early Oligocene time (Fassoulas et al., 1994; Fig. 7). In response to continuing Africa-Eurasia convergence, northward subduction was initiated within the remaining, more southerly Neotethyan strand, which was previously passive. Possibly in response to this subduction, the lowest units in the thrust stack (Phyllite-Quartzite and Plattenkalk) underwent high-pressure metamorphism, dated as late Oligocene (Seidel et al., 1982). Protoliths are interpreted as a carbonate platform unit (i.e., the Plattenkalk unit) that was dismembered, subducted, underplated and then exhumed to its present structural position. It is likely that this subduction-accretion was contemporaneous with the early stages of accretion of the Mediterranean Ridge.

By the late middle Miocene a south-Aegean landmass was actively disintegrating, in response to progressive regional crustal extension. Pulsed uplift of Crete took place from the early Pliocene onwards, coupled with marginal subsidence (Meulenkamp et al., 1988, 1994). Normal faulting during the Pliocene-Pleistocene eventually exposed all levels of the thrust stack, such that the highest mountains are formed of Mesozoic platform carbonate rocks located relatively deep in the overall thrust stack. Uplift was accompanied by deep erosion and cutting of gorge systems, releasing huge volumes of sediment into the deep Mediterranean Sea to the south.

\section{EVOLUTION OF THE MEDITERRANEAN RIDGE ACCRETIONARY COMPLEX}

The early subduction-accretion history is important, as most studies tend to assume that the clasts and matrix of the mud volcanoes

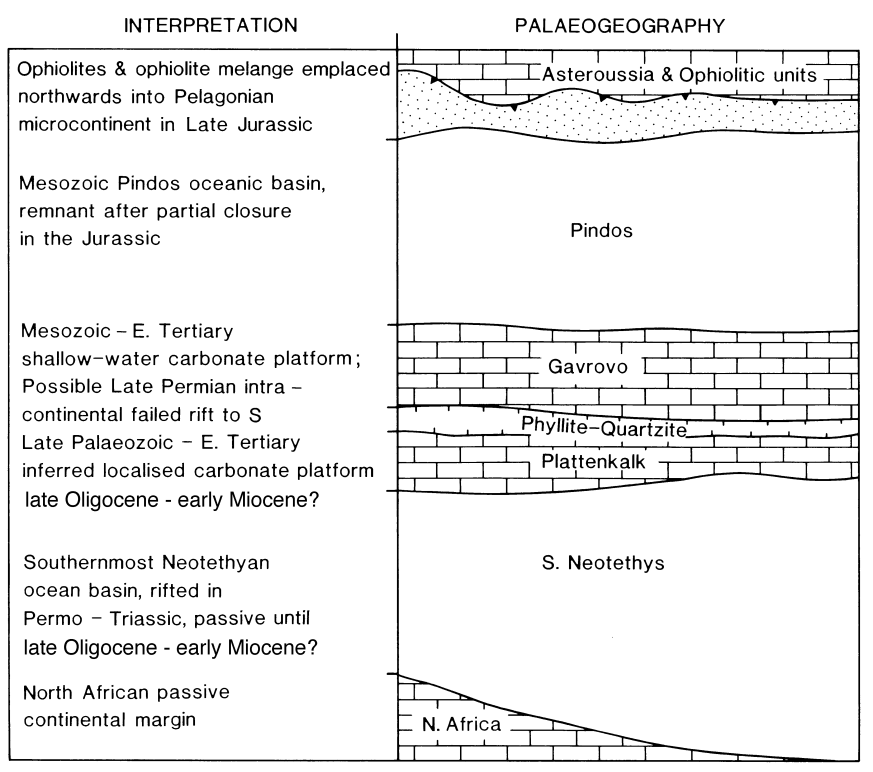

Figure 5. Paleogeographic sketch of the south Aegean in the Late Cretaceous. By this time, the Neotethyan Pindos ocean to the north was partially closed with ophiolite and melange emplacement in the Late Jurassic. Further south, a southerly microcontinent was originally rifted from Gondwana in the Permian-Triassic. This was part of Apulia (or Adria) and was composed shallow-water carbonate platforms (i.e., Gavrovo, Plattenkalk, and PhylliteQuartzite units). The southernmost strand of Neotethys remained open to the north, bordered by passive margins. were derived from an underlying layer-cake succession beneath (Premoli-Silva et al., 1996; van der Zel and Woodside, 1997; Akhmanov and Woodside, Chap. 46, this volume). In reality, the source was controlled by three main factors: (1) regional stratigraphy, (2) subduction-accretion, and (3) backthrusting, or out-of-sequence thrusting. The clasts in any given mud volcano may thus have originated in different locations at different times within the Eastern Mediterranean deep basin and may already have been variably displaced as allochthonous units related to subduction, prior to onset of mud volcanism at about $1 \mathrm{Ma}$ before present.

\section{Oligocene-Miocene}

Northward subduction possibly began in the late Oligocene (around $33 \mathrm{M}$ a; Kastens, 1991), consistent with the evidence, mentioned above, of high pressure metamorphism in Crete and adjacent areas, and onset of arc-related volcanism to the north (e.g., Santorini; Fytikas et al., 1984; Piper and Piper, 1989). However, seismic tomographic evidence suggests earlier commencement of subduction (Spakmann et al., 1988), whereas a Miocene age (13 Ma) was also proposed by Le Pichon and Angelier (1979).

After onset of subduction, previously emplaced thrust sheets to the north would have acted as a relatively rigid backstop. The start of northward subduction might have resulted in an increase in terrigenous input into the Eastern Mediterranean basin, reflecting tectonic destabilization of both the northerly (south Aegean) and southerly (north African) continental margins.

Assuming subduction began in the late Oligocene, one possibility is that accretion of the Mediterranean Ridge dates from this time (Kastens, 1991). Accretion might have been accentuated in the early Miocene (Serravallian) in conjunction with southward roll-back of the Aegean arc and regional back-arc extension (Kissel and Laj, 1988; Kastens, 1991). Alternatively, for Limonov et al. (1996) the accretionary wedge only grew rapidly in the late Miocene. They suggested this because they thought that clastic sediments forming mud clasts were locally derived sediments not deposited on the abyssal plain. However, evidence from sedimentary structures shows that these clasts are mainly turbidites (Akmanov, 1996; Robertson and Kopf, Chap. 45, this volume).

The following hypothesis is proposed (Fig. 7). During initial stages subduction (late Oligocene-early Miocene), the downgoing slab comprised a relatively slowly deposited lower unit of mainly early Tertiary and Mesozoic deep-water carbonates (with early Mesozoic oceanic crust beneath; de Voogd et al., 1992), overlain by more rapidly deposited Oligocene-Miocene siliciclastic and calcareous turbidites. The lower unit is rarely preserved (see below), whereas upper unit lithologies dominate the mud volcano clasts. The OligoceneMiocene sediments accumulated on the abyssal plain, and in the subduction trench if one then existed as a morphological feature. An inferred rheological boundary between a lower unit, which was older, slowly deposited, and compacted, and an upper unit, which was more rapidly deposited and less compacted, would represent an obvious plane of décollement. The lower unit was detached and subducted, whereas the upper unit was accreted to form a late OligoceneMiocene accretionary prism.

The older clasts (late Aptian red pelagic limestone) within the mud breccias might represent remnants of topographic highs on the downgoing slab that were preferentially accreted (e.g., a drowned carbonate platform). The Cretaceous clasts are composed of red and green limestones, ranging from semi-indurated to lithified $(0.1-7 \mathrm{~cm}$ in size; Premoli-Silva et al., 1996). Some limestones are brecciated with recrystallized carbonate forming microveins. The reddishbrown pelagic limestone are comparable with the Scisti a Fucoidi from the Umbria and Marche basins of mainland Italy. Also, in the Greek and Turkish area, comparable Mesozoic shallow-water carbonate platforms include reddish pelagic carbonates (e.g., in the Antalya Complex; see Gutnic et al., 1979; Robertson et al., 1991). In addition, clasts of red pelagic limestone were also recorded from the 


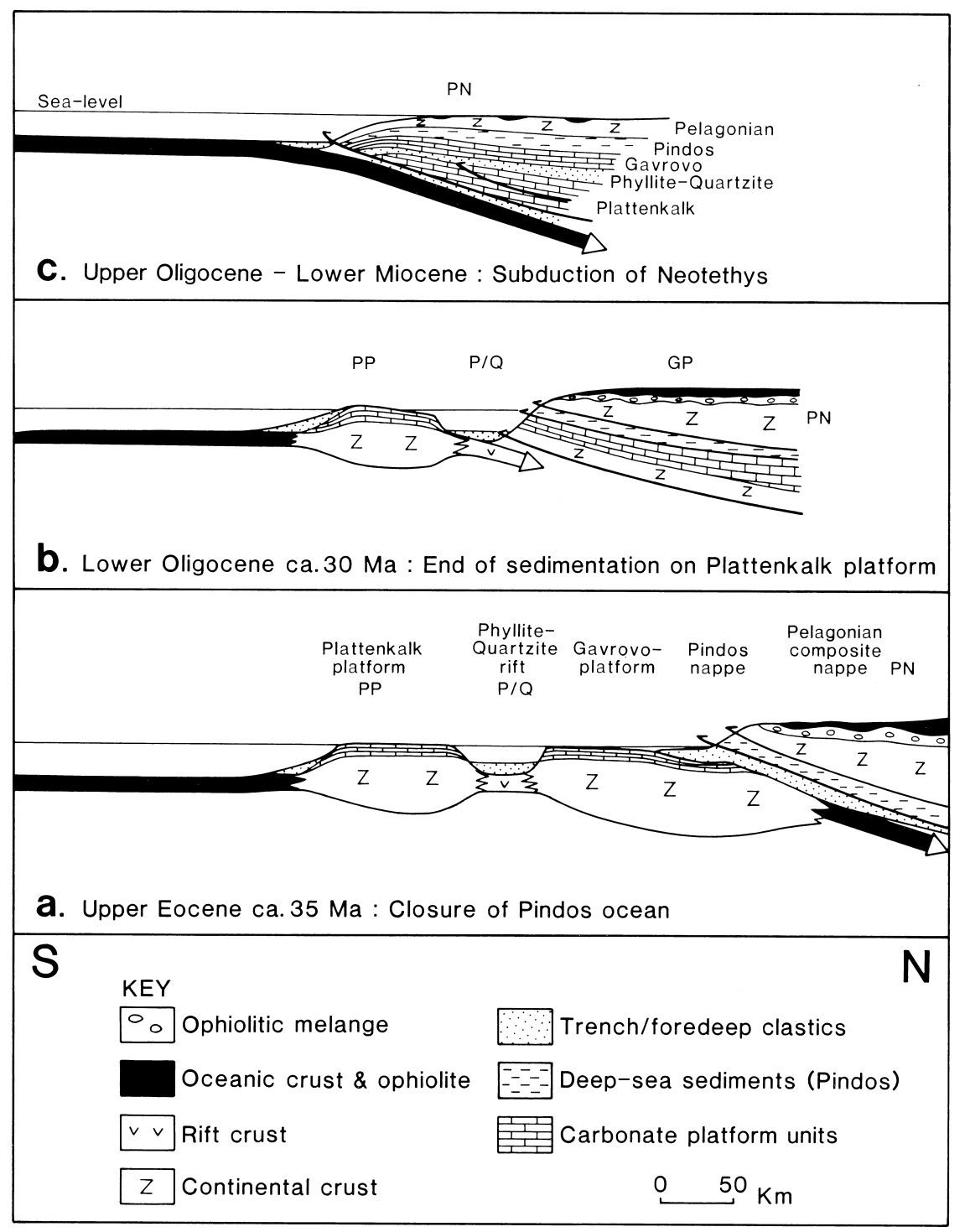

Figure 6. Plate-tectonic sketches to show the proposed assembly of the Cretan thrust stack. A. The Pindos ocean finally closed driving allochthonous units over the Gavrovo platform unit. B. The Gavrovo unit carbonate platform was accreted to the base of the overriding thrust stack and the Phyllite-Quartzite and Plattenkalk units began to be overthrust. C. Northward subduction of the southernmost Neotethys began and the Phyllite-Quartzite and Plattenkalk units were underplated and metamorphosed to high pressure. Accretion of the Mediterranean Ridge was initiated. Uplift and exhumation of the Cretan thrust stack began in the late Miocene and continued in the PliocenePleistocene.
Prometheus mud volcano (approximately $400 \mathrm{~km}$ northwest of the Olimpi mud volcanoes; Ryan et al., 1982) and these might also relate to accretion of a pelagic carbonate succession on a topographic high.

The existence of a pre-Messinian décollement is supported by seismic reflection studies of the southwestern Mediterranean Ridge area (Reston et al., 1995) and theoretical considerations (Sample, 1990). Also, the central segment of the Mediterranean Ridge is distinguished by strongly deformed deep seismic units, overlain by weakly deformed seismic units. This discontinuity could be explained by the existence of a gentle unconformity (Chaumillon and Mascle, in press a), related to erosion in the Messinian (Hsü et al., 1977). This central part of the accretionary wedge was probably part of an early accretionary wedge prior to the Messinian.

In a simple subduction-accretion model the sequence of thrusting is such that the age of the accreted material is expected to be progressively younger towards the toe of the accretionary wedge (i.e., toward the south). In contrast, in the Olimpi mud volcano field, relatively old (i.e., late Aptian aged) clasts are found in a relatively southerly position (i.e., the unnamed mud volcano; Premoli-Silva et al., 1996). The clast-age distribution is not easily explained by simple in-sequence subduction-accretion. Backthrusting of the Mediterranean Ridge accretionary wedge might provide an explanation (i.e., younger units were accreted, then thrust northwards). However, seismic images indicate the backthrusts are of too high an angle (Chaumillon and Mas- cle, 1995, in press) to permit such large-distance lateral translation. Another possibility is that out-of-sequence thrusting might have complicated the thrust stacking order, as observed in Barbados (Brown and Westbrook, 1987).

\section{Late Miocene}

During the Messinian, the deep Mediterranean was overlain by thick evaporites (Hsü et al., 1973; Hsü, Montadert, et al., 1978; Fig. 7). Kilometer-thick evaporites accumulated on the abyssal plain and in any subduction trench that was then present. A new rheological contrast was thereby created regionally, marked by an underlying Miocene and older, partly lithified, siliciclastic/carbonate sequence, and an overlying poorly consolidated Messinian evaporite sequence. Seismic data for the Ionian segment of the Mediterranean Ridge (as part of the IMERSE Project) confirm that the subduction décollement now lies within the Messinian interval for the first 80 kilometers behind the deformation front, and then cuts into deeper levels, beneath a pre-Messinian accretionary wedge, that is imaged as imbricate thrust slices (Reston et al., 1995). This evidence implies that décollement zone did indeed migrate stratigraphically upward with time in this area. The angle of dip of the subduction zone beneath the older, deeper part of the wedge is $1^{\circ}-2^{\circ}$ (Kastens et al., 1992; Reston et al., 1995) and, by extrapolation, the décollement is inferred to lie at $\sim 5-$ 

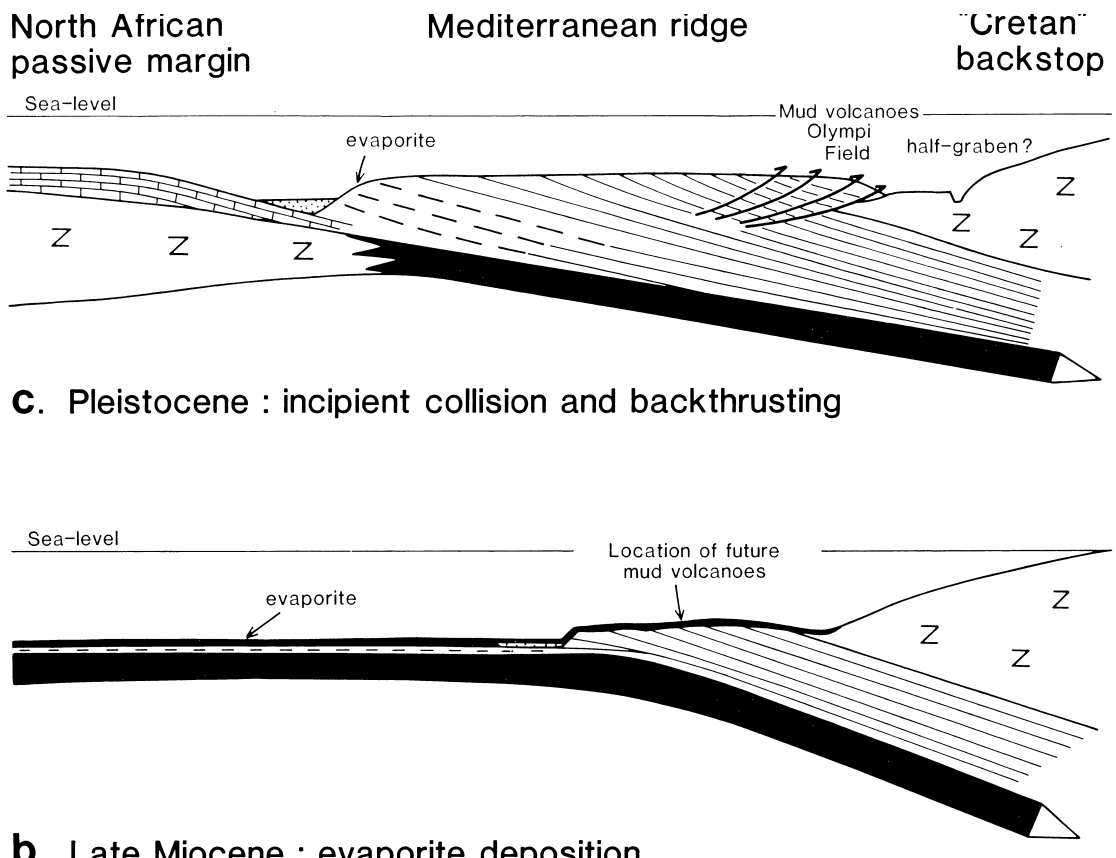

b. Late Miocene : evaporite deposition

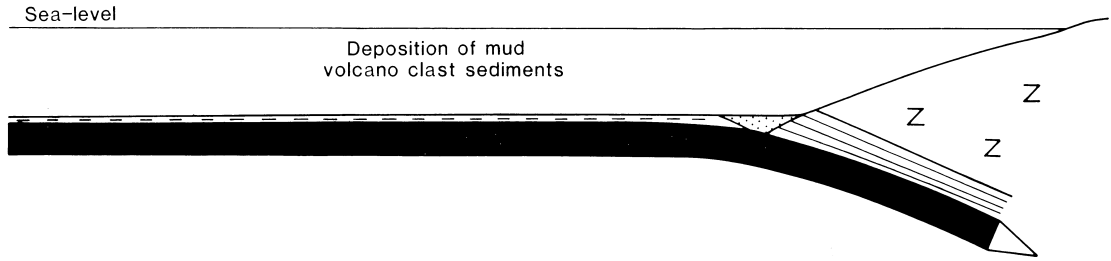

\section{a. Upper Oligocene : initial accretionary prism}

Figure 7. Stages in the development of the Mediterranean Ridge accretionary complex. A. Steady-state subduction beneath Crete. B. Construction of a wedge of late Oligocene?-middle Miocene deep-sea sediments. C. Messinian, followed by initiation of backthrusting as the Mediterranean Ridge accretionary complex began to collide with the Cyrenaica promontory of the North African passive margin to the south. Upward stepping of the décollement to within the

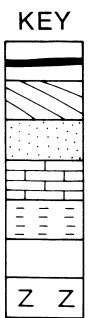

$7 \mathrm{~km}$ below the Olimpi mud volcano field (Camerlenghi et al., 1995). From the late Miocene onward, the décollement was located within the incoming Messinian succession and, thus, the accreted material was poorly consolidated Messinian mud, clay, evaporite, and sand.

\section{Pliocene-Pleistocene}

Seismic evidence indicates that the Mediterranean Ridge accretionary complex is now being backthrust over a backstop of relatively rigid Cretan crust (Camerlenghi et al., 1995; Reston et al., 1995; Chaumillon et al., in press, Fig. 4). Backthrusting is also widespread, actually within the accretionary complex (Chaumillon and Mascle, 1995, in press). Backthrusting is known to take place associated with accretionary complexes undergoing steady-state subduction in a noncollisional setting (e.g., Barbados; Brown and Westbrook, 1988).
Messinian evaporite

Accretionary prism

Trench clastics

Continental margin sediments

Pelagic and hemipelagic sediments

Oceanic and transitional crust

Continental crust

Such backthrusting is typically a response to the need to maintain a gravitational stable "critical taper," as the accretionary wedge buildups on the seaward side of the subduction zone (Platt, 1990). This explanation is, however, unlikely in the case of the Mediterranean Ridge accretionary complex as the frontal portion of the wedge is dominated by rheologically very weak Messinian to PlioceneQuaternary sediments that would not support a steep wedge topography. Instead, the key factor is that the accretionary complex is in the process of collision with the Cyrenaica promontory of North Africa (Camerlenghi et al., 1995; Fig. 1). As a result of progressive collision, the accretionary wedge was uplifted and backthrust over the backstop of Cretan continental crust, at least in the central segment of the Mediterranean Ridge, including the Olimpi mud volcano field (Fig. 4).

Backthrusting had two main consequences. First, new thrusts propagated against the structural grain of the previous Oligocene- 
Miocene accretionary wedge, possibly resulting in tectonic fragmentation, and thus a possible means of formation of some clasts in the mud volcano sediments. Backthrust accretionary complexes on land reveal very complex structural patterns, including genesis of "broken formation" transitional to tectonic melange (e.g., in the Antalya Complex, southwest Turkey; Waldron, 1984). Secondly, backthrusts could provide zones of egress of fluids and fluidized sediments from depth within the accretionary complex, thus helping to explain the location of the mud volcanoes to the rear of the subduction complex

\section{PREVIOUS MODELS OF MEDITERRANEAN RIDGE MUD VOLCANISM OR MUD DIAPIRISM}

Ryan et al. (1982) envisioned the mud volcanism as the result of protrusion of mud from through an accretionary prism on a vast scale related to steady state subduction (Fig. 8).

Camerlenghi et al. (1995) proposed a model whereby the Mediterranean Ridge mud volcanism relates to northward subduction and discharge of mud from depth $(5-7 \mathrm{~km})$ from zones of backthrusting. Gas-rich mud first erupted on the surface and spread laterally into a circular depression caused by collapse of the host sediments as a result of degassing (Fig. 9A). This was followed by liquid mud extrusion, causing interfingering with surrounding pelagic sediments. During the final stage of eruption, viscous mud was intruded, causing uplift to form a cone-shaped mud dome, the "Olimpi structure."

Limonov et al. (1996) also inferred an origin of the Olimpi mud volcanoes related to compression of the Mediterranean Ridge accretionary complex. The mud was squeezed out from within any part of the underlying accretionary complex that contains abundant clay. The emplacement took place northward (implying a dominant role of backthrusting) at a relatively low angle $\left(45^{\circ}\right)$ from a vast source of water- and gas-saturated mud beneath. There was no well defined plumbing system, or relation to any underlying décollement. The age of the clasts in the mud breccias could be more or less random. Messinian evaporites were thought not to play any particular role.

Chaumillon and Mascle (1995, in press) argue that collision of the Mediterranean Ridge with North Africa already occurred before Messinian time, suggesting that the mud volcanoes developed in an advanced collisional setting. Assuming present-day subduction rates (3-5 cm/yr; e.g., Kastens, 1991), up to $200 \mathrm{~km}$ of convergence could have taken place in this area since the Miocene. However, taking account also of the southward migration of the Aegean arc (Le Pichon and Angelier, 1979; Kissel and Laj, 1988) a total convergence rate of $7 \mathrm{~cm} / \mathrm{yr}$ is implied, that would correspond to approximately a $400 \mathrm{~km}$ length of the North African plate passing beneath the Mediterranean Ridge convergence front since the Miocene. It is very unlikely that as much of the North African passive continental margin has yet been subducted, given that the deformation front is still located on the lower continental slope, without strong uplift of the overriding plate of foreland basin development. For example, the present situation contrasts with the incipient collisional setting of the Eratosthenes Seamount, in which the leading edge of the overriding plate in (i.e., southern Cyprus) has been strongly uplifted (Emeis, Robertson, Richter, et al., 1966). Chaumillon and Mascle (1995, in press) also suggested that mud volcanism might be related to the activity of several rather than one décollement level within the Mediterranean Ridge accretionary wedge, one at the base of the Messinian evaporites and a second located within Aptian shales. The Leg 160 data support the presence of a décollement zone within Messinian evaporitebearing sediments. The localized presence of Cretaceous clasts can be explained by other processes (see above) without need to invoke a coeval deeper-level décollement zone.

Fusi and Kenyon (1996) note that the mud volcanoes parallel the tectonic grain of the Mediterranean Ridge accretionary complex and propose a structural control associated with deep-seated structures.
Noting the preferred northwest-southeast alignment of the mud volcanoes, Hieke et al. (1996b) suggest that the location of the mud structures is controlled by fault crossings that are exploited as mud conduits. These authors envision the Olimpi area as being influenced by faulting associated with both a northwest-southeast trend as observed in the west (Ionian segment), and a northeast-southwest trend active to the east (e.g., Strabo trench). However, direct evidence of cross-cutting fault patterns around individual mud volcanoes is lacking, and the presence of elongate structures need only imply a locally elongate (fault controlled?) source of mud rather than connection with far removed tectonic elements. In addition, Galindo-Zaldivar et al. (1996) interpret a southward concave pattern of lineaments around the Olimpi field as symmetric folds related to a subsurface décollement. However, similar elongate features are interpreted by Hieke et al. (1996b) as fault controlled, and it is possible that the arcuate pattern is related to large-scale collapse of sediment compensating for the expulsion of large volumes of mud within the Olimpi field.

There is also the question of whether the mud structures are mud volcanoes, mud diapirs, or both. Some of the mud structures are interpreted as diapiric structures, with the implication that vast volumes of material were protruded above the seafloor without lateral flow (Limonov et al., 1994; Ivanov et al., 1996; Hieke et al., 1996b). In addition, the Prometheus 2 and Pan di Zucchero mud structures (Fig. 2) were also interpreted as diapirs (Cita et al., 1989; Camerlenghi et al., 1992). However, mud flows were observed that have emanated from discrete craters during several cruises (Limonov et al., 1994), and high resolution surveys reveal elongate tongue-like structures (Limonov et al., 1994; Hieke et al., 1996b) that can be interpreted as mud flows. Also, drilling up to 200 mbsf deep holes into the contrasting Milano and Napoli mud domes during Ocean Drilling Program (ODP) Leg 160 has provided no evidence for an intrusive mechanism. Where large (kilometer-sized) features are imaged flowage onto the seafloor a debris flow deposit is likely.

In summary, it is likely that most or all of the large circular to subcircular features are mud volcanoes. However, the presence of some true diapiric structures (e.g., mud ridges) cannot be ruled out, especially were marginal deformation is observed.

\section{REVISED HYPOTHESIS OF MUD VOLCANISM}

The North African margin represents part of the passive margin of Gondwana, dating from rifting in late Permian? to early Mesozoic time, to form the Neotethys ocean. Several microcontinents were rifted from Gondwana and then drifted toward the Eurasia margin during Mesozoic time (Fig. 5). During the early Tertiary, remnants of Neotethyan microcontinents and small ocean basins in the north were progressively accreted to the southern margin of Eurasia. By the upper Eocene-early Oligocene collisions were creating a vast edifice of thrust sheets, including the Cretan nappes (Fig. 6). Metamorphic and some ophiolitic rocks formed the highest levels of the thrust stack, and were the first to be exposed during exhumation, mainly in the Pliocene-Pleistocene time, by a combination of erosion and extensional faulting.

With continued convergence of the African and Eurasian plates, the southernmost Neotethyan basin (i.e., the Eastern Mediterranean) began to be subducted (Fig. 7A), beginning in the late Oligocene?early Miocene initiating the Mediterranean Ridge accretionary complex (Fig. 7B). The décollement zone of the incoming plate was possibly located at a rheological boundary between underlying upper Cretaceous-early Tertiary mainly deep-sea carbonate successions, and overlying Oligocene-Miocene mainly siliciclastic and calcareous turbidites. Initially subducted material may be represented by the high pressure units at the lowest levels of the Cretan thrust stack. During the late Oligocene and early-middle Miocene a wedge of siliciclastic turbidites, calciturbidites, pelagic carbonate, mud, and clay 


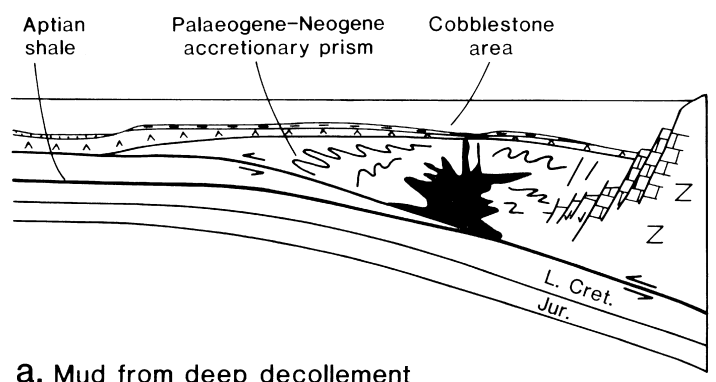
(Prometheus area)

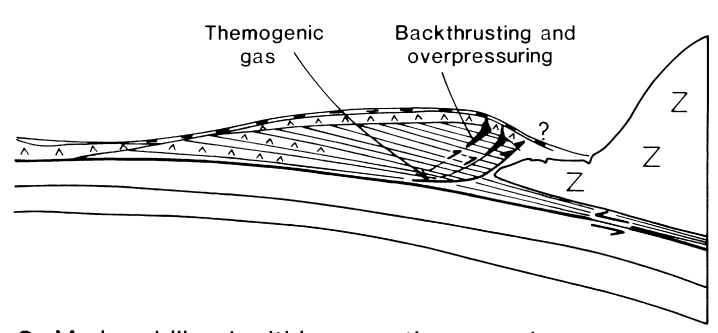

C. Mud mobilised within accretionary prism related to back-thrusting, supply of overpressured and thermogenic gas from decollement zone

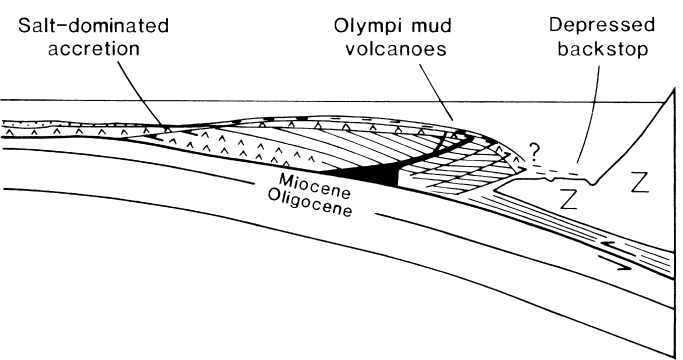

b. Mud from shallow decollement related to back-thrusting

KEY

--:- Plio-Quaternary deep-sea mud

Clastics

$\wedge \wedge$ Evaporites (Messinian)

Limestone (Cretan)

$Z$ Backstop of emplaced thrust sheets

$\left[\begin{array}{l}0 \\ 10\end{array}\right.$

Figure 8. Alternate hypothetical tectonic setting of mud volcanism on the Mediterranean Ridge: (A) related to steady-state subduction/accretion with fluid-rich mud expelled from above the downgoing slab (5-7 km; Ryan et al., 1982); (B) related to backthrusting of the mud-dominated Mediterranean Ridge accretionary wedge with fluidized mud derived from the décollement zone (Camerlenghi et al., 1995); (C) related to backthrusting that squeezed mud from the higher levels of the accretionary wedge with little or no sediment input from the décollement below. Vitrinite reflectance data support mud mobilization (as in B). See text for discussion.

A CAMERLENGHI et al., 1995

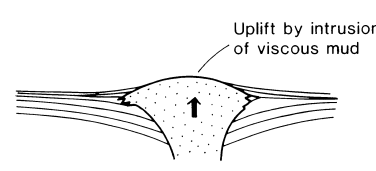

3 Late stage

$$
\text { e.g. Milano }
$$$$
\text { mud diap }
$$

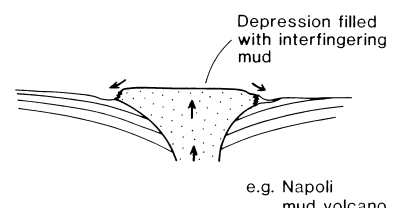

2 Intermediate stage

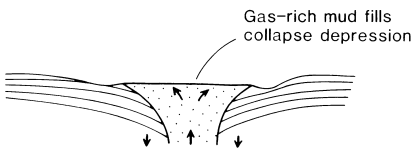

1 Initial stage

\section{B THIS STUDY}

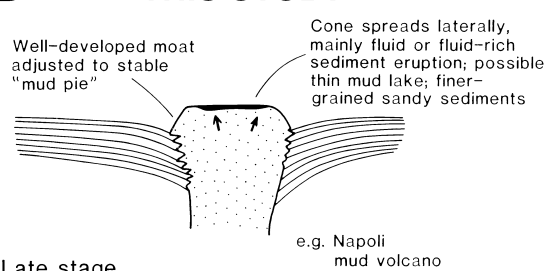

3 Late stage

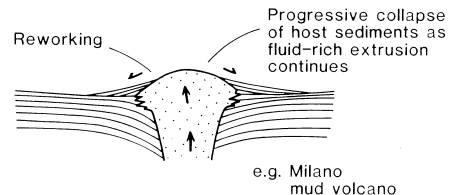

2 Intermediate stage

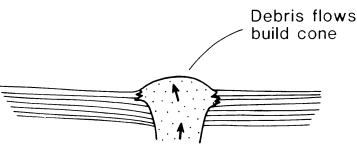

1 Initial stage 
was accreted to form a precursor of the Mediterranean Ridge. The main source is presumed to have been the North African passive margin, but a small amount of lithic and ophiolitic clastic material was also derived from the north (i.e., from Crete, or other parts of the south Aegean landmass).

During the Messinian, thick evaporites draped the Mediterranean deep-basins, including the abyssal plain, and the trench (if present), to the south of the then-existing Mediterranean ridge accretionary complex (Fig. 7C). A new rheological contrast developed between already cemented sands and carbonates below, and unconsolidated muds, silts, and sands above. As a response to changed rheology, the décollement then stepped upwards, such that material within the décollement zone from then onwards was then mainly of late Miocene age (i.e., clay, mud, sand, and evaporite), as observed in the matrix of the mud volcanoes. The incorporation of rheologically weak evaporite, as subduction-accretion continued, allowed the accretionary wedge to spread out laterally, explaining the absence of a morphological trench today. An impermeable layer of gypsum (i.e., the "M" reflector) on top of the accretionary prism prevented pore fluid escape at this stage and favored the presence of underconsolidated mud underneath the evaporite. However, thick evaporites are absent from the crestal areas of the accretionary wedge as a whole.

During the late Pliocene-Pleistocene, the by-then broadened Mediterranean Ridge accretionary complex first collided with the Cyrenaica promontory of the North African passive margin, initiating backthrusting to maintain a critical taper. Previously accreted, mainly Miocene sediments were tectonically fragmented in response to backthrusting, providing zones of egress for overpressured fluid mud originating within the décollement zone. Upward-moving fluids (including dissolved gas) were initially impeded by a cap of impermeable evaporites (and gas hydrate?). When the combined lithostatic/ hydrostatic load was exceeded, as backthrusting intensified, the Messinian layer was punctured and mud volcanism began. Gas, predominantly methane, is known to follow the subduction trace; e.g., in Barbados (Martin et al., 1996). This implies that high pore fluid pressures compensate for lithostatic load even deep within the subduction zone, and this allows mud to remain unconsolidated. Variable mobilization and pulsed upward migration may then control extrusion on the seafloor (Yassir and Bell, 1994).

After mobilization, upward flow of mud took place, mainly derived from the Messinian evaporite-rich sediment in the vicinity of the décollement. In Barbados the décollement acts a fluid reservoir, separated by impermeable barriers. The décollement zone is about 25 $m$ thick and exhibits scaly fabrics, fracture networks, and interleaving of both intact and disrupted sediment, and is interpreted as a probable zone of high in situ fluid pressure (Shipley, Ogawa, Blum et al., 1995), as also supported by in situ permeability tests in the Cascadia accretionary prism (Screaton et al., 1995).

The backthrust zone presumably channeled fluid egress. If so, backthrusts were active for $>1 \mathrm{Ma}$, presumably related to uplift of the Mediterranean Ridge Inner Plateau area (Fig. 10). The sediments of the overlying, pre-existing accretionary wedge were by then variably lithified. The rising fluid-rich mud physically detached and entrained clasts of sandstone and limestone. At higher levels ( $<2 \mathrm{~km} \mathrm{mbsf})$ upward transport was possibly aided by expansion caused by gradual release of methane from solution (i.e., resulting in increase in porosity and decrease in density), limited, however, by the high hydrostatic pressure (i.e., $2000 \mathrm{~m}$ water depth; e.g., Brown, 1990). Substantial volumes of gas are assumed to have been liberated during extrusion.

The clast disaggregation was achieved by a combination of (1) fault brecciation during original accretion, before mud volcanism; (2) physical abrasion and faulting (i.e., fragmentation of accreted strata) during physical uprise of mud, as fault breccia along backthrusts; (3) hydrofracturing related to release in pressure as overpressured gasrich, fluidized muds were erupted.

Once the mud reached the seafloor, it was extruded to form an initial mud-rich cone (Fig. 9B). Hydrofracturing and shearing of clasts indicate the eruptive nature at the early stages of mud volcanism in the Olimpi field. Clasts were abraded to become mainly subangular to subrounded during upward movement of material. Large volumes of generally coarser debris flows were subsequently extruded, and now form the base and flanks of the mud volcanoes. Extrusion of large volumes of overpressured, fluidized mud was accompanied by subsidence to form a peripheral moat, which either remained as a seafloor feature (e.g., Napoli), or was filled with sediment (e.g., Milano). Between phases of eruptive activity, the mud structures were draped by hemipelagic sediment. A capping of impermeable gas hydrate may then have formed, as in the Milano mud volcano, trapping large volumes of natural gas tens of meters beneath the seafloor. The low permeabilities of the mud breccias suggest that repeated pressure build up could easily have taken place, even in the absence of gas hydrate. Intercalations of clay-rich debris flows and turbidites may record episodes of reworking off the cone, possibly triggered by renewed extrusions. The cone eventually reached the maximum height that could be supported by the pressure head and then spread out laterally to produce a flat top (similar to the "mud pies" of Barbados; Langseth and Moore, 1990). Fluid-rich muds may then have erupted to form superficial mud lakes, including more sandy sediment (i.e., Napoli).

The mud volcanoes can be envisioned as alternately dormant for long periods (e.g., Milano) and active for shorter periods (e.g., Napoli). Dormant phases were characterized by (1) reworking and surficial draping by hemipelagic sediments according to local topography and bottom current activity; (2) development of gas hydrate caps at shallow depth beneath the seafloor; (3) gradual increase in pore pressures at depth related to such ongoing tectonic processes as subduction and backthrusting. By contrast, active phases of eruption were marked by (1) decomposition of any gas hydrate (as relatively warm fluids reached the seafloor); (2) extrusion of multiple debris flows; (3) gravity reworking off existing cones; (4) peripheral subsidence to formmoat-like structures; (5) release of overpressuring at depth, sufficiently to halt further eruption.

\section{CONCLUSIONS}

1. The Milano and Napoli mud volcanoes are mainly composed of sedimentary debris flow deposits and are not viscous mud intrusions, as previously suggested;

2. The Milano and Napoli mud volcanoes are more than $1 \mathrm{Ma}$ old, much older than previously envisioned;

3. The driving force of Mediterranean Ridge volcanism was northward subduction and collision. Overpressured, fluid-rich sediments escaped when steep backthrusts developed in response to collision of the North African passive margin with a relatively rigid backstop of Cretan continental crust to the north;

4. Early-middle Miocene limestone, mudstone, claystone, and undated quartzose sandstones were derived from previously lithified units within the pre-exiting accretionary wedge. Clasts were created by physical abrasion, faulting, or hydraulic fracturing. Some rounding took place during ascent to the surface;

5. Evidence of very low permeabilities of the mud breccia is consistent with episodic pressure build-up and release by repeated eruption;

6. The décollement zone from which much of the mud matrix was derived was located within late Miocene evaporite-rich sediments, probably at a depth of approximately $5-7 \mathrm{~km}$. However, plumbing systems of individual mud volcanoes appear to differ.

7. Initial, possibly forceful, eruption formed a cone of clast-rich debris flows and polymict gravels, which were then blanketed by suspension deposits. Subsequently, large volumes of multiple debris flows were erupted quiescently;

8. Shallow bacterial degradation of organic matter gave rise to large volumes of hydrocarbon gas, as confirmed by the gassy nature of 
Figure 10. Revised model of mud volcanism on the ported by petrographic and mineralogic data from Leg 160. Mud volcanism was initiated approximately $>1 \mathrm{Ma}$ ago, following collision of the toe of the Mediterranean ridge accretionary complex with a promontory of the North African passive continental margin. To maintain a critical taper, northward backthrusting was initiated over a rigid backstop of Cretan continental crust. A Messinian evaporite seal (presumably gypsum) was later punctured, initiating mud volcanism. High fluid pressures within the décollement drove upward fluid flow along back-thrusts, causing partial fluidization of early-middle Miocene accretionary prism sediments to form clast- and matrix-rich material that was eventually extruded onto the seafloor as multiple debris flows. Mediterranean Ridge accretionary complex, sup-

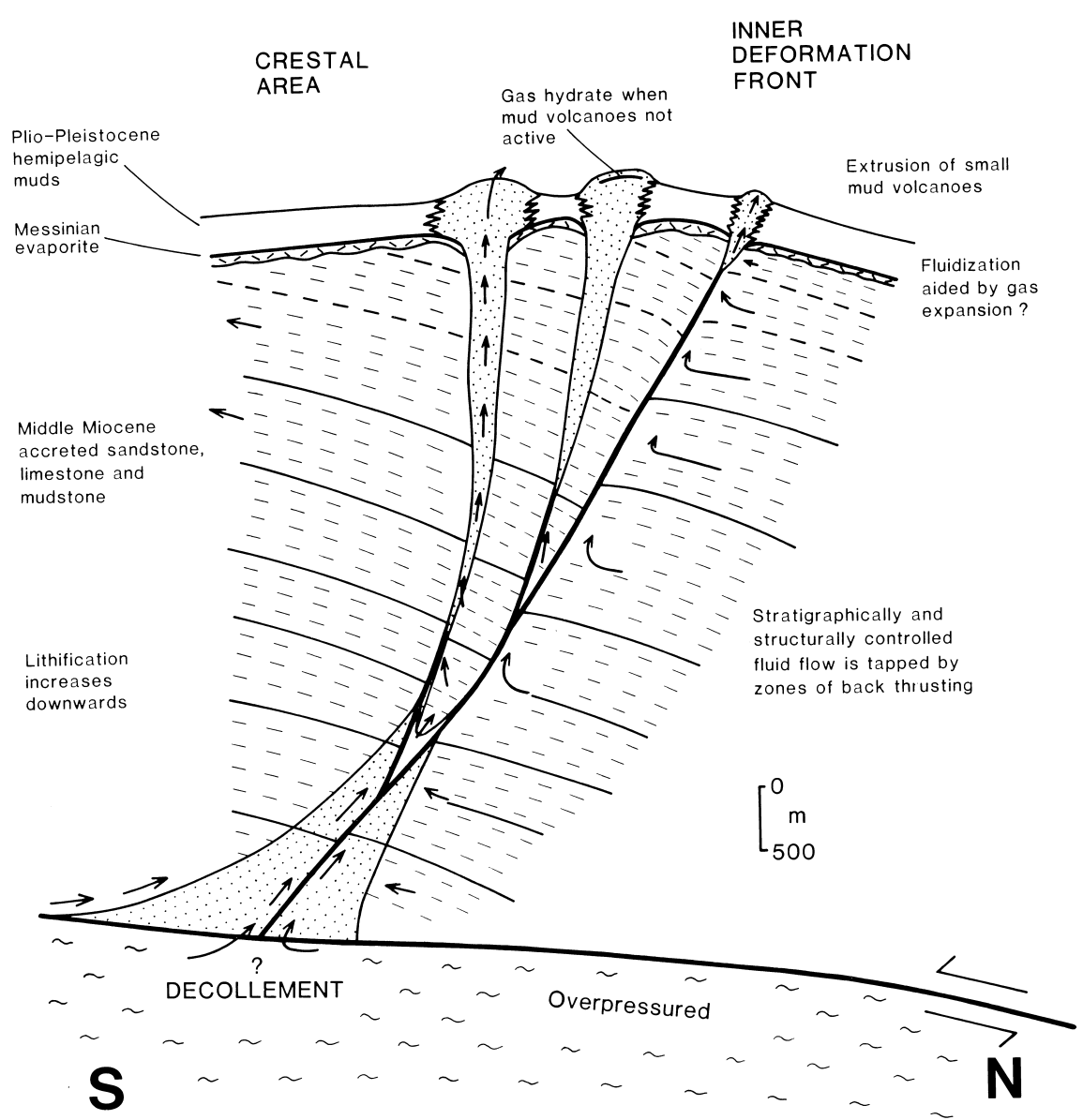

sediments on the active Napoli mud volcano. In addition, the presence of mature hydrocarbon gas at Napoli confirms the presence of a deep hydrocarbon source. Seafloor conditions were suitable for gas hydrates to be preserved near the surface mainly within the Milano mud volcanoes; and

9. Provenance studies of clasts indicate that, whereas most of the sediment was derived from the North African passive continental margin to the south, some lithoclastic material, including some of inferred ophiolitic origin, was derived from the northerly active margin, with implications for the exhumation history of Crete and adjacent areas of the south Aegean.

\section{ACKNOWLEDGMENTS}

Our thanks go to the captain, crew, and marine technicians during Leg 160 for their outstanding support. Dana Bay assisted with drafting; Yvonne Cooper helped with photography. Silvia Spezzaferri, Rachel Flecker, Ben Clennell, Najwa Yassir, and Angelo Camerlenghi are thanked for discussion. The manuscript benefited from comments by Angelo Camerlenghi and Werner Hieke. Achim Kopf received funding through Grant Be 1041-10 by Deutsche Forschungsgemeinschaft.

\section{REFERENCES}

Agar, S.M., 1990. The interaction of fluid processes and progressive deformation during shallow level accretion: examples from the Shimanto Belt of SW Japan. J. Geophys. Res., 95:9133-9148.

Akmhanov, G.G., 1996. Lithology of mud breccia clasts from the Mediterranean Ridge. Mar. Geol., 132:151-164.
Barber, A.J., Tjokrosapoetro, S., and Charlton, T.R., 1986. Mud volcanoes, shale diapirs, wrench faults, and melanges in accretionary complexes, Eastern Indonesia. AAPG Bull., 70:1729-1741.

Beeby-Thomson, A., 1910. The oilfields of Trinidad. West Indian Committee, Pamphlet 12.

Behrmann, J.H., 1991. Conditions for hydrofracture and the fluid permeability of accretionary wedges. Earth Planet. Sci. Lett., 107:550-558.

Belenkaia, I., 1997. Carbonate nodules: mineralogical and isotopic characteristics of the authigenic carbonates of the Black Sea. Congr. Gas Fluids in Marine Sediments, Amsterdam, 13. (Abstract)

Brown, K.M., 1990. The nature and hydrogeologic significance of mud diapirs and diatremes for accretionary systems. J. Geophys. Res., 95:89698982.

Brown, K.M., and Westbrook, G.K., 1987. The tectonic fabric of the Barbados Ridge Accretionary Complex. Mar. Pet. Geol., 4:71-81.

1988. Mud diapirism and subcretion in the Barbados Ridge Complex. Tectonics, 7:613-640.

Camerlenghi, A., Cita, M.B., Della Vedova, B., Fusi, N., Mirabile, L., and Pellis, G., 1995. Geophysical evidence of mud diapirism on the Mediterranean Ridge accretionary complex. Mar. Geophys. Res., 17:115-141.

Camerlenghi, A., Cita, M.B., Hieke, W., and Ricchiuto, T.S., 1992. Geological evidence for mud diapirism on the Mediterranean Ridge accretionary complex. Earth Planet. Sci. Lett., 109:493-504.

Camerlenghi, A., and Polonia, A., 1994. Variation of structural style along the eastern Mediteranean Ridge accretionary complex from the MS-multichannel seismic dataset. 1994 Spring Meeting of AGU, Eos Suppl., 117. , in press. The Mediterranean Ridge: a salt-bearing accretionary compex in the framework of continental collision. In Cloething, S.A.P.L., and Sarti, M. (Eds.), Sedimentary Basins: Models and Constraints. Proc. Internat. School Earth and Planetary Sciences, Siena (Italy), September 1996.

Chase, C.G., 1978. Plate kinematics: the Americas, East Africa, and the rest of the world. Earth Planet. Sci. Lett., 37:355-368. 
Chaumillon, E., and Mascle, J., 1995. Variation laterale des fonts de deformation de la Ride mediterraneenne (Mediterranee orientale). Bull. Soc. Geol. Fr., 166:463-478.

- in press. From foreland to forearc domains: new multichannel seismic reflection survey of the Mediterranean Ridge accretionary complex (Eastern Mediterranean). Mar. Geol.

Chaumillon, E., Mascle, J., and Hoffmann, H.J., in press. Deformation of the western Mediterranean Ridge: importance of Messinian evaporitic formations. Tectonophysics.

Cita, M.B., Camerlenghi, A., Erba, E., McCoy, F.W., Castradori, D., Cazzani, A., Guasti, G., Giambastiani, M., Lucchi, R., Nolli, V., Pezzi, G., Redaelli, M., Rizzi, E., Torricelli, S., and Violanti, D., 1989. Discovery of mud diapirism in the Mediterranean Ridge: a preliminary report. Boll. Soc. Geol. Ital., 108:537-543.

Cita, M.B., Erba, E., Lucchi, R., Pott, M., van der Meer, R., and Nieto, L., 1996. Stratigraphy and sedimentation in the Mediterranean Ridge diapiric belt. Mar. Geol., 132:131-150.

Cita, M.B., Ryan, W.B.F., and Paggi, L., 1981. Prometheus mud-breccia: an example of shale diapirism in the Western Mediterranean Ridge. Ann. Geol. Pays Hellen., 30:543-570.

Clennell, B., and Maltman, A., 1995. Microstructures in accreted sediments of the Cascadia Margin. In Carson, B., Westbrook, G.K., Musgrave, R.J., and Suess, E. (Eds.), Proc. ODP, Sci. Results, 146 (Pt 1): College Station, TX (Ocean Drilling Program), 201-216.

Corselli, C., and Basso, D., 1996. First evidence of benthic communities based on chemosynthesis on tbe Napoli mud volcano (Eastern Mediterranean). Mar. Geol., 132:227-239.

Cronin, B.T., Ivanov, M.K., Limonov, A.F., Egorov, A., Akhmanov, G.G., Akhmetjanov, A.M., Kozlova, E.V., and Shipboard Scientific Party TTR5, 1997. New discoveries of mud volcanoes on the Eastern Mediterranean Ridge. J. Geol. Soc. London, 154:173-182.

Dercourt, J., Ricou, L.F., and Vrielynck, B. (Eds.), 1993. Atlas of Tethys Palaeoenvironmental Maps: Paris (Gauthier-Villars).

de Voogd, B., Truffert, C., Chamot-Rooke, N., Huchon, P., Lallemant, S., and Le Pichon, X., 1992. Two-ship deep seismic soundings in the basins of the eastern Mediterranean Sea (Pasiphae cruise). Geophys. J. Int., 109:536-552.

Emeis, K.-C., Robertson, A.H.F., Richter, C., et al., 1996. Proc. ODP, Init. Repts., 160: College Station, TX (Ocean Drilling Program).

Fassoulas, C., Kilias, A., and Mountrakis, D., 1994. Post nappe stacking and extension of high-pressure/low-temperature rocks in the island of Crete, Greece. Tectonics, 13:127-138.

Finetti, I., 1976. Mediterranean Ridge: a young submerged chain associated with the Hellenic Arc. Boll. Geofis. Teor. Appl., 19:31-65.

Finetti, I.R., Bricchi, G., Den Ben, A., Pipan, M., and Xuan, Z., 1988. Geophysical study of the Black Sea. In Finetti, I.R. (Ed.), Monograph on the Black Sea. Boll. Geofis. Teor. Appl., 30:197-324.

Flecker, R., and Kopf, A., 1996. Data report: clast and grain size analysis of sediment recovered from the Napoli and Milano mud volcanoes, Eastern Mediterranean. In Emeis, K.-C., Robertson, A.H.F., Richter, C., et al., Proc. ODP, Init. Repts., 160: College Station, TX (Ocean Drilling Program), 529-532.

Fusi, N., and Kenyon, N., 1996. Distribution of mud diapirism and other geological structures from long-range sidescan sonar (GLORIA) data, in the Eastern Mediterranean Sea. Mar. Geol., 132:21-38.

Fytikas, M., Innocenti, P., Manetti, P., Mazzuoli, R., Peccerillo, A., and Villari, L., 1984. Tertiary to Quaternary evolution of volcanism in the Aegean region. In Dixon, J.E., and Robertson, A.H.F. (Eds.), The Geological Evolution of the Eastern Mediterranean. Spec. Publ. Geol. Soc. London, 17:687-700.

Gainanov, V., 1997. Features of the Black Sea mud volcanoes and mud diapirs according to sesimic data. Congr., Gas and Fluids in Mar. Sediments, Amsterdam, 35. (Abstract)

Galindo-Zaldivar, J., Nieto, L., and Woodside, J., 1996. Structural features of mud volcanoes and the fold system of the Mediterranean Ridge, south of Crete. Mar. Geol., 132:95-112.

Gutnic, M., Monod, O., Poisson, A., and Dumont, J.-F., 1979. Géologie des Taurides occidentales (Turquie). Mem. Soc. Geol. Fr., 137:1-112.

Hall, R., Audley-Charles, M.G., and Carter, D.J., 1984. The significance of Crete for the evolution of the Eastern Mediterranean. In Dixon, J.E., and Robertson, A.H.F. (Eds.), The Geological Evolution of the Eastern Mediterranean. Geol. Soc. Spec. Publ. London, 17:499-516.

Henry, P., Le Pichon, X., Lallemant, S., Foucher, J.-P., Westbrook, G., and Hobart, M., 1990. Mud volcano field seaward of the Barbados accretion- ary complex: a deep-towed side scan sonar survey. J. Geophys. Res., 95:8917-8929.

Henry, P., Le Pichon, X., Lallemant, S., Lance, S., Martin, J.B., Foucher, J.P., Fiala-Médioni, A., Rostek, F., Guilhaumou, N., Pranal, V., and Castrec, M., 1996. Fluid flow in and around a mud volcano field seaward of the Barbados accretionary wedge: results from Manon cruise. J. Geophys. Res., 101/B9:20297-20323.

Hieke, W., Cita, M.B., Mirabile, G.L., Negri, A., and Werner, F., 1996a. The summit area (Antaeus/Pan di Zucchero) of the Mediterranean Ridge: a mud diapir field? Mar. Geol., 132:113-129.

Hieke, W., Werner, F., and Schenke, H.-W., 1996b. Geomorphological study of and area with mud diapirs south of Crete (Mediterranean Ridge). Mar. Geol., 132:63-93.

Higgins, G.E., and Saunders, J.B., 1974. Mud volcanoes-their nature and origin: contributions to geology and palaeobiology of Caribbean and adjacent areas. Verh. Naturforsch. Ges. Basel, 84:101-152.

Hsü, K.J., Cita, M.B., and Ryan, W.B.F., 1973. The origin of the Mediterranean evaporites. In Ryan, W.B.F., Hsü, K.J., et al., Init. Repts. DSDP, 13 (Pt. 2): Washington (U.S. Govt. Printing Office), 1203-1231.

Hsü, K.J., Montadert, L., Bernoulli, D., Cita, M.B., Erickson, A., Garrison, R.E., Kidd, R.B., Meliéres, F., Müller, C., and Wright, R., 1977. History of the Mediterranean salinity crises. Nature, 267:399-403.

Hsü, K.J., Montadert, L., et al., 1978. Init. Repts. DSDP, 42 (Pt. 1): Washington (U.S. Govt. Printing Office).

Huchon, P., Lyberis, N., Angelier, J., Le Pichon, X., and Renard, V., 1982. Tectonics of the Hellenic Trench: a synthesis of sea-beam and submersible observations. Tectonophysics, 86:9-112.

Ivanov, M.K., Limonov, A.F., and van Weering, T.C.E., 1996. Comparative characteristics of the Black Sea and Mediterranean Ridge mud volcanoes. Mar. Geol., 132:253-271.

Jakubov, A.A., Ali-Zade, A.A., and Zeinalov, M.M., 1971. Mud Volcanoes of the Azerbaijan SSR: Baku (Publ. House Acad. Sci. Azerbaijan SSR).

Kastens, K.A., 1991. Rate of outward growth of the Mediterranean Ridge accretionary complex. Tectonophysics, 199:28-50.

Kastens, K.A., Breen, N.A., and Cita, M.B., 1992. Progressive deformation on an evaporite-bearing accretionary complex: SeaMARC 1, SeaBeam, and piston-core observations from the Mediterranean Ridge. Mar. Geophys. Res., 14:249-298.

Kimura, G., Silver, E., Blum, P., et al., 1997. Proc. ODP, Init. Repts., 170, College Station, TX (Ocean Drilling Program).

Kissel, C., and Laj, C., 1988. The Tertiary geodynamical evolution of the Aegean Arc: a paleomagnetic reconstruction. Tectonophysics, 146:183201.

Kopf, A., Robertson, A.H.F., Clennell, M.B., and Flecker, R., in press. Mechanisms of mud extrusion on the Mediterranean Ridge Accretionary Prism. Geo-Mar. Lett.

Lallemant, S., Truffert, C., Jolivet, L., Henry, P., Chamot-Rooke, N., and de Voogd, B., 1994. Spatial transition from compression to extension in the Western Mediterranean Ridge accretionary complex. Tectonophysics, 234:33-52.

Langseth, M.G., and Moore, J.C., 1990. Introduction to special section on the role of fluids in sediment accretion, deformation, diagenesis, and metamorphism in subduction zones. J. Geophys. Res., 95:8737-8741.

Langseth, M.G., Westbrook, G.K., and Hobart, M.A., 1988. Geophysical survey of a mud volcano seaward of the Barbados Ridge accretionary complex. J. Geophys. Res., 93:1049-1061.

Le Pichon, X., and Angelier, J., 1979. The Hellenic arc and trench system: a key to the neotectonic evolution of the eastern Mediterranean area. Tectonophysics, 60:1-42.

Le Pichon, X., Chamot-Rooke, N., Lallement, S., Noomen, R., and Veis, G., 1995. Geodetic measurements of the kinematics of central Greece with respect to Europe: implications for eastern Mediterranean tectonics. $J$. Geophys. Res., 100:1275-12690.

Le Pichon, X., Foucher, J.-P., Boulegue, J., Henry, P., Lallemant, S., Benedetti, M., Avedik, F., and Mariotti, A., 1990. Mud volcano field seaward of the Barbados accretionary complex: a submersible survey. J. Geophys. Res., 95:8931-8943.

Le Pichon, X., Lyberis, N., Angelier, J., and Renard, V., 1982. Strain distribution over the East Mediterranean Ridge: a synthesis incorporating new Sea Beam data. Tectonophysics, 86:243-274.

Limonov, A.F., Ivanov, M.K., Meisner, L.B., and Kozlova, E.V., 1997. Structure of sedimentary cover in the Sorokin Trough (South of Crimea) and related mud volcanism. Congr., Gas and Fluids in Mar. Sediments, 7. (Abstract). 
Limonov, A.F., Woodside, J.M., Cita, M.B., and Ivanov, M.K., 1996. The Mediterranean Ridge and related mud diapirism: a background. Mar. Geol., 132:7-19.

Limonov, A.F., Woodside, J.M., and Ivanov, M.K. (Eds.), 1994. Mud Volcanism in the Mediterranean and Black Seas and Shallow Structure of the Eratosthenes Seamount. Initial Results of the Geological and Geophysical Investigations during the Third "Training-through-Research" Cruise of the R/V Gelendzhik (June-July 1993). UNESCO Rep. Mar. Sci., 64.

Martin, B.M., Kastner, M., Henry, P., Le Pichon, X., and Lallement, S., 1996. Chemical and isotopic evidence for sources of fluids in a mud volcano field seaward of the Barbados accretionary wedge. J. Geophys. Res., 101:20325-20345.

Meulenkamp, J.E., van der Zwaan, G.J., and van Wamel, W.A., 1994. On Late Miocene to Recent vertical motions in the Cretan segment of the Hellenic arc. Tectonophysics, 234:53-72.

Meulenkamp, J.E., Wortel, M.J.R., van Wamel, W.A., Spakman, W., and Hoogerduijn Strating, E., 1988. On the Hellenic subduction zone and the geodynamic evolution of Crete since the late middle Miocene. Tectonophysics, 146:203-215.

Morgan,. J.K., and Karig, D.E., 1995. Décollement processes at the Nankai accretionary margin, Southeast Japan. J. Geophys. Res., 100/B8:1522115231.

Piper, G., and Piper, D.J.W., 1989. Spatial and temporal variation in the Late Cenozoic back-arc volcanic rocks, Aegean Sea region. Tectonophysics, 169:113-134.

Platt, J.P., 1990. Thrust mechanics in highly pressured accretionary wedges. J. Geophys. Res., 95:9025-9034.

Premoli-Silva, I., Erba, E., Spezzaferri, S., and Cita, M.B., 1996. Age variation in the source of the diapriric mud breccias along and across the axis of the Mediterranean Ridge Accretionary Complex. Mar. Geol., 132:175-202.

Prior, D.J., and Behrmann, J.H., 1990. Thrust-related mudstone fabrics from the Barbados forearc: a backscattered scanning electron microscope study. J. Geophys. Res., 95:9055-9067.

Reed, D.L., Silver, E.A., Tagudin, J.E., Shipley, T.H., and Vrolijk, P., 1990. Relations between mud volcanoes, thrust deformation, slope sedimentation and gas hydrates, offshore north Panama. Mar. Pet. Geol., 7:44-54.

Reston, T.J., von Huene, R., Fruehn, J., and Dickman, T., 1995. A section across the Mediterranean Ridge-results of the IMERSE project. Eos, Am. Geophys. Union, Fall Meeting Suppl., F625.

Robertson, A.H.F., Clift, P.D., Degnan, P., and Jones, G., 1991. Palaeogeographic and palaeotectonic evolution of the Eastern Mediterranean Neotethys. Palaeogeogr. Palaeoclimatol., Palaeoecol., 87:289-344.

Robertson, A.H.F., Emeis, K.-C. (Co-Chief Scientists), Richter, C. (Staff Scientist), Blanc-Valleron, M.-M., Bouloubassi, I., Brumsack, H.J., Cramp, A., Di Stefano, G.J., Flecker, R., Frankel, E., Howell, M.W. Janecek, T.R., Jurado-Rodriguez, M.-J., Kemp, A.E.S., Koizumi, I., Kopf, A., Major, C.O., Mart, Y., Pribnow, D.F.C., Rabaute, A., Roberts, A.P., Rullkötter, J.H., Sakamoto, T., Spezzaferri, S., Staerker, T.S., Stoner, J.S., Whiting, B.M. and Woodside, J.M., 1996. Mud volcanism on the Mediterranean Ridge: Initial results of the Ocean Drilling Program Leg 160. Geology, 24:239-242.

Robertson, A.H.F., Emeis, K.-C. (Co-Chief Scientists), Richter, C. (Staff Scientist), Blanc-Valleron, M.-M., Bouloubassi, I., Brumsack, H.J., Cramp, A., Di Stefano, G.J., Flecker, R., Frankel, E., Howell, M.W., Janecek, T.R., Jurado-Rodriguez, M.-J., Kemp, A.E.S., Koizumi, I., Kopf, A., Major, C.O. Mart, Y., Pribnow, D.F.C., Rabaute, A., Roberts, A.P., Rullkötter, J.H., Sakamoto, T., Spezzaferri, S., Staerker, T.S., Stoner, J.S., Whiting, B.M. and Woodside, J.M., 1997. Collision-related break-up of a carbonate platform (Eratosthenes Seamount) and mud volcanism on the Mediterranean Ridge: preliminary synthesis and implications of tectonic results of ODP Leg 160 in the Eastern Mediterranean Sea. In Cramp, A., MacLeod, C.J., Lee, S.V., and Jones, E.J.W. (Eds.), Geological Evolution of Ocean Basins. Geol. Soc. Spec. Publ. London, 131:243-271.

Ryan, W.B.F., and Hsü, K.J., et al., 1973. Hellenic Trench Sites 127 and 128. In Ryan, W.B.F., and Hsü, K.J., et al., Init. Repts. DSDP, 13 (Pt. 2): Washington (U.S.Govt. Printing Office), 243-322.

Ryan, W.B.F., Kastens, K.A., and Cita, M.B., 1982. Geological evidence concerning compressional tectonics in the Eastern Mediterranean. Tectonophysics, 86:213-242.

Sample, J.C., 1990. The effects of carbonate cementation of underthrust sediments on deformation styles during underplating. J. Geophys. Res., 95:9111-9121.
Sample, J.C., and Kopf, A., 1995. Isotope geochemistry of syntectonic carbonate cements and veins from the Oregon Margin: implications for the hydrogeologic evolution of the accretionary wedge. In Carson, B., Westbrook, G.K., Musgrave, R.J., and Suess, E. (Eds.), Proc. ODP, Sci. Results, 146 (Pt 1): College Station, TX (Ocean Drilling Program), 137148.

Sample, J.C., Reid, M.R., Tobin, H.J., and Moore, J.C., 1993. Carbonate cements indicate channeled fluid flow along a zone of vertical faults at the deformation front of the Cascadia accretionary wedge (Northwest U.S. coast). Geology, 21:507-510.

Sancho, J., Letouzey, J., Biju-Duval, B., Courrier, P., Montadert, L., and Winnock, E., 1973. New data on the structure of the Eastern Mediterranean basin from seismic reflection. Earth Planet. Sci. Lett., 18:189-204.

Schultheiss, P.J., and Gunn, D.E., 1985. The permeability and consolidation of deep-sea sediments. Inst. Oceanogr. Sci. Rep., 201.

Schultz, H.-M., 1997. Organic carbon provenance and maturity in the mud breccias from the Napoli mud volcano: indicators of origin and burial depth. Earth Planet. Sci. Lett., 147:141-151.

Screaton, E.J., Carson, B., and Lennon, G.P., 1995. In situ permeability tests at Site 892: characteristics of a hydrogeologically active fault zone on the Oregon accretionary prism. In Carson, B., Westbrook, G.K., Musgrave, R.J., and Suess, E. (Eds.), Proc. ODP, Sci. Results, 146 (Pt 1): College Station, TX (Ocean Drilling Program), 291-297.

Seidel, E., Kreuzer, H., and Harre, W., 1982. A late Oligocene/early Eocene high pressure belt in the external Hellenides. Geol. Jahrb., E23:165-206.

Shih, T., 1967. A survey of active mud volcanoes in Taiwan and a study of their types and the character of the mud. Petrol. Geol. Taiwan, 5:259311.

Shipley, T.H., Ogawa, Y., Blum, P., et al., 1995. Proc. ODP, Init. Repts., 156: College Station, TX (Ocean Drilling Program).

Shipley, T.H., Stoffa, P.L., and Dean, D.F., 1990. Underthrust sediments, fluid migration paths, and mud volcanoes associated with the accretionary wedge off Costa Rica: Middle America trench. J. Geophys. Res., 95:8743-8752.

Spakmann, W., Wortel, M.J.R., and Vlaar, N.J., 1988. The Hellenic subduction zone: a tomographic image and its geodynamic implications. Geophys. Res. Lett., 15:60-63.

Staffini, F., Spezzaferri, S., and Aghib, F., 1993. Mud diapirs of the Mediterranean Ridge: sedimentological and micropalaeontological study of the mud breccia. Riv. Ital. Paleontol. Stratigr., 99:225-254.

Truffert, C., Chamot-Rooke, N., Lallemant, S., de Voogd, B., Huchon, P., and Le Pichon, X., 1993. The crust of the Western Mediterranean Ridge from deep seismic data and gravity modelling. Geophys. J. Int., 114:360-372.

Tugoleslov, D.A., Gorshkov, A.S., Meisner, L.B., and Solov'ev, V.V., 1985. Tectonics of Mesozoic-Cenozoic Deposits of the Black Sea Basin: Moscow (Nedra).

van der Zel, C.J., and Woodside, J.M., 1997. Gas and Fluids in Marine Sediments, Congr., 38. (Abstract)

Vereshchagin, V.N., and Kovtunovich, Y.M. (Eds.), 1970. Geologiya SSSR: Ostrov Sakhalin: Moscow (Nedra).

Waldron, J.W.F., 1984. Evolution of carbonate platforms on a margin of the Neotethys ocean: Isparta angle, south-western Turkey. Eclogae Geol. Helv., 77:553-581.

Westbrook, G.K., Carson, B., Musgrave, R.J., et al., 1994. Proc. ODP, Init. Repts., 146 (Pt. 1): College Station, TX (Ocean Drilling Program).

Westbrook, G.K., and MEDRIFF Consortium, 1995. Three brine lakes discovered in the seafloor of the Eastern Mediterranean. Eos, 76/33:313315 .

Woodside, J.M., 1997. The Anaximander Mountains in their geological context. Gas and Fluids in Marine Sediments, Congr., 17. (Abstract)

Yassir, N.A., 1989. Mud volcanoes and the behaviour of overpressured clays and silts [Ph.D. thesis]. London.

Yassir, N.A., and Bell, J.S., 1994. Relationships between pore pressures, stresses and present-day geodynamics in the Scotian Shelf, Offshore Eastern Canada. AAPG Bull., 78:1863-1880.

Date of initial receipt: 13 August 1997

Date of acceptance: 21 October 1997

Ms 160SR-062 